Louisiana State University

LSU Digital Commons

4-13-2015

\title{
Synthesis of 3,8-Dichloro-6-ethyl-1,2,5,7-tetramethyl-BODIPY from an Asymmetric Dipyrroketone and Reactivity Studies at the 3,5,8-Positions
}

\author{
Ning Zhao \\ Louisiana State University \\ M. Graça H. Vicente \\ Louisiana State University \\ Frank R. Fronczek \\ Louisiana State University \\ Kevin M. Smith \\ Louisiana State University
}

Follow this and additional works at: https://digitalcommons.Isu.edu/chemistry_pubs

\section{Recommended Citation}

Zhao, N., Vicente, M., Fronczek, F., \& Smith, K. (2015). Synthesis of 3,8-Dichloro-6-ethyl-1,2,5,7-tetramethylBODIPY from an Asymmetric Dipyrroketone and Reactivity Studies at the 3,5,8-Positions. Chemistry - $A$ European Journal, 21 (16), 6181-6192. https://doi.org/10.1002/chem.201406550

This Article is brought to you for free and open access by the Department of Chemistry at LSU Digital Commons. It has been accepted for inclusion in Faculty Publications by an authorized administrator of LSU Digital Commons.

For more information, please contact ir@lsu.edu. 
Louisiana State University

LSU Digital Commons

4-13-2015

\title{
Synthesis of 3,8-Dichloro-6-ethyl-1,2,5,7-tetramethyl-BODIPY from an Asymmetric Dipyrroketone and Reactivity Studies at the 3,5,8-Positions
}

\author{
Ning Zhao \\ Louisiana State University \\ M. Graça H. Vicente \\ Louisiana State University \\ Frank R. Fronczek \\ Louisiana State University \\ Kevin M. Smith \\ Louisiana State University
}

Follow this and additional works at: https://digitalcommons.Isu.edu/chemistry_pubs

\section{Recommended Citation}

Zhao, N., Vicente, M., Fronczek, F., \& Smith, K. (2015). Synthesis of 3,8-Dichloro-6-ethyl-1,2,5,7-tetramethylBODIPY from an Asymmetric Dipyrroketone and Reactivity Studies at the 3,5,8-Positions. Chemistry - $A$ European Journal, 21 (16), 6181-6192. https://doi.org/10.1002/chem.201406550

This Article is brought to you for free and open access by the Department of Chemistry at LSU Digital Commons. It has been accepted for inclusion in Faculty Publications by an authorized administrator of LSU Digital Commons.

For more information, please contact ir@lsu.edu. 


\title{
Synthesis of 3,8-Dichloro-6-ethyl-1,2,5,7-tetramethyl-BODIPY from an Asymmetric Dipyrroketone and Reactivity Studies at the 3,5,8-Positions ${ }^{*}$
}

\author{
Ning Zhao, Prof. Dr. M. Graça H. Vicente, Dr. Frank R. Fronczek, and Prof. Dr. Kevin M. \\ Smith \\ Department of Chemistry, Louisiana State University, Baton Rouge, LA, 70803 (USA) \\ M. Graça H. Vicente: vicente@Isu.edu
}

\begin{abstract}
The asymmetric BODIPY 1a (BODIPY=4,4-difluoro-4-bora-3a,4a-diaza- $s$-indacene), containing two chloro substituents at the 3,8-positions and a reactive 5-methyl group, was synthesized from the asymmetric dipyrroketone $\mathbf{3}$, which was readily obtained from available pyrrole $\mathbf{2 a}$. The reactivity of 3,8-dichloro-6-ethyl-1,2,5,7-tetramethyl-BODIPY 1a was investigated by using four types of reactions. This versatile BODIPY undergoes regioselective $\mathrm{Pd}^{0}$-catalyzed Stille coupling reactions and/or regioselective nucleophilic addition/elimination reactions, first at the 8-chloro and then at the 3-chloro group, using a variety of organostannanes and $\mathrm{N}-, \mathrm{O}-$, and $\mathrm{S}$-centered nucleophiles. On the other hand, the more reactive 5-methyl group undergoes regioselective Knoevenagel condensation with an aryl aldehyde to produce a monostyryl-BODIPY, and oxidation with 2,3-dichloro-5,6-dicyano-1,4-benzoquinone (DDQ) gives the corresponding 5formyl-BODIPY. Investigation of the reactivity of asymmetric BODIPY 1a led to the preparation of a variety of functionalized BODIPYs with $\lambda_{\max }$ of absorption and emission in the ranges 487587 and 521-617 nm, respectively. The longest absorbing/emitting compound was the monostyryl-BODIPY 16, and the largest Stokes shift (49 nm) and fluorescence quantum yield (0.94) were measured for 5-thienyl-8-phenoxy-BODIPY 15. The structural properties (including $16 \mathrm{X}$-ray structures) of the new series of BODIPYs were investigated.
\end{abstract}

\section{Keywords}

addition/elimination; BODIPY; fluorescence; $\mathrm{Pd}^{0}$-catalyzed coupling; oxidation; substitution

\section{Introduction}

4,4-Difluoro-4-bora-3a,4a-diaza-s-indacene dyes, known generically as borondipyrromethenes or BODIPYs, are very versatile compounds that have attracted much attention since they were first reported in $1968 .^{[1]}$ Due to their remarkable properties,

\footnotetext{
** BODIPY=4,4-Difluoro-4-bora-3a,4a-diaza-s-indacene.

(C) 2015 Wiley-VCH Verlag GmbH\& Co. KGaA, Weinheim

Correspondence to: M. Graça H. Vicente, vicente@lsu . edu.

Supporting information for this article is available on the WWW under http://dx.doi.org/10.1002/chem.201406550.
} 
including high extinction coefficients, and generally high fluorescence quantum yields, low molecular weights, and high thermal and photochemical stabilities, ${ }^{[2]}$ BODIPYs have been actively investigated in protein ${ }^{[3]}$ and DNA-labeling, ${ }^{[3 a, 4]}$ drug delivery, ${ }^{[3 a, 5]}$ lightharvesting arrays, ${ }^{[6]}$ fluorescent switches, ${ }^{[7]}$ and in medical imaging and theranostics. ${ }^{[8]}$

A traditional approach to the synthesis of BODIPY scaffolds involves the condensation reaction between excess a-free pyrroles and aldehydes ${ }^{[9]}$ in the presence of a Lewis acid, followed by DDQ oxidation to dipyrromethene, and then boron complexation, using boron trifluoride diethyl etherate under basic conditions. Alternatively, a-free pyrroles react with acid chlorides ${ }^{[10]}$ or anhydrides ${ }^{[1]}$ to directly yield dipyrromethenes. Another efficient methodology for the preparation of both symmetric and asymmetric meso-free BODIPYs is by condensation of a 2-formylpyrrole with an a-free pyrrole by using $\mathrm{POCl}_{3}$ as a catalyst, followed by boron complexation. ${ }^{[12]}$ Similarly, meso-aryl BODIPYs can be prepared from the reaction of 2-ketopyrrole ${ }^{[13]}$ with an a-free pyrrole fragment. ${ }^{[14]}$ Alternatively, the synthesis of symmetric 8-functionalized BODIPYs has been reported via a dipyrrothioketone ${ }^{[15]}$ or dipyrroketone ${ }^{[16]}$ intermediate; this route offers expeditious access to 8-thio or 8-halo-BODIPYs, respectively.

Using the above methods, a number of BODIPY platforms, such as those in Figure 1, have been synthesized and their reactivity investigated. ${ }^{[2]}$ For example, the a-methyl groups on BODIPY platform a undergo Knoevenagel condensations with various aldehydes, to produce the corresponding styryl-BODIPYs that display significant redshifted absorption and emission spectra. ${ }^{[17]}$ On the other hand, BODIPY platform $\mathbf{b}$ bearing 3,5-chloro groups undergoes milder $\mathrm{Pd}^{0}$-catalyzed cross-coupling reactions and nucleophilic substitution reactions at these positions, producing a variety of functionalized BODIPYs for various applications. ${ }^{[18]}$ Functionalizations at the 8-position of BODIPYs are reported for platform c, ${ }^{[15,19]}$ which undergoes nucleophilic addition/elimination and Liebeskind-Srogl crosscoupling reactions, and also for platform $\mathbf{d}$ bearing an 8-chloro group. ${ }^{[16]}$ Compared with the 8-methylthio-BODIPY $\mathbf{c}$, platform $\mathbf{d}$ is more versatile, reacting with a variety of $\mathrm{N}-, \mathrm{O}-$, and $\mathrm{S}$-centered nucleophiles, as well as under a variety of $\mathrm{Pd}^{0}$-catalyzed Stille, Suzuki, and Sonogashira coupling conditions, producing the corresponding functionalized BODIPYs in good to quantitative yields.

We have recently synthesized a symmetric 3,5,8-trichloro-BODIPY dye and explored its regioselectivity in Stille cross-coupling conditions. ${ }^{[20]}$ Herein we report the synthesis of a versatile, asymmetric BODIPY 1a bearing two chloro substituents at positions 3 and 8 , as well as a reactive 5-methyl group, starting from an asymmetric dipyrroketone. We show that BODIPY 1a can be regioselectively functionalized using four types of reactions, at positions 3,5 and 8 , to produce new conjugated BODIPYs. The nucleophilic addition/elimination and cross-coupling reactions both occur regioselectively at the 8-chloro followed by the 3-chloro position, allowing stepwise functionalization using various organometallic reagents and $\mathrm{N}-$, $\mathrm{O}-$, and S-centered nucleophiles. This is the first report on the meso-versus a-position regioselectivity of BODIPY nucleophilic reactions. Furthermore, the 5-methyl group undergoes regioselective Knoevenagel and oxidation reactions, providing access to additional functionalized BODIPY platforms. The structural and spectroscopic properties of the new BODIPYs were investigated. 


\section{Results and Discussion}

\section{Synthesis and structural characterization}

The synthetic route to asymmetric 3,8-dichloro-BODIPY 1a is outlined in Scheme 1. The conversion of the a-methyl group of readily available pyrrole $\mathbf{2} \mathbf{a}^{[21]}$ to a carboxylic acid produced $\mathbf{2 b},{ }^{[22]}$ which was acylated with thionyl chloride followed by reaction with dimethylamine gas ${ }^{[22 b]}$ affording 5 -( $N, N$-dimethylamido) pyrrole $2 \mathrm{c}$ in $85 \%$ yield. The asymmetric dipyrroketone $\mathbf{3}$ was prepared by reaction of pyrrole $\mathbf{2} \mathbf{c}$ with phosphoryl chloride, followed by addition of commercially available 3-ethyl-2,4-dimethylpyrrole and subsequent hydrolysis using aqueous sodium acetate ${ }^{[23]}$ in $86 \%$ overall yield. When excess phosgene was used to convert dipyrroketone 3 to the corresponding 5-chlorodipyrrin salt, the dipyrryl salt $\mathbf{4}$ was obtained instead by chlorination of the the a-methyl group of $\mathbf{3}$, probably due to the presence of the electron-withdrawing benzyl ester. ${ }^{[20]}$ Therefore, the benzyl ester was converted to an iodide by debenzylation followed by decarboxylative iodination ${ }^{[24]}$ producing dipyrroketone $\mathbf{5}$ in $84 \%$ overall yield. The reaction of $\mathbf{5}$ with excess phosgene (15\% in toluene) was accompanied by a color change from yellow to dark red, along with a down-field shift of the NH protons in the ${ }^{1} \mathrm{H}$ NMR spectrum. Subsequent boron complexation using excess $\mathrm{BF}_{3} \cdot \mathrm{OEt}_{2}$ and $N, N$-diisopropylethylamine (DIEA) produced BODIPY 1a in $78 \%$ overall yield. The trans-chlorination of the 1-iododipyrroketone has been previously observed under these reaction conditions; ${ }^{[20]}$ in addition, the 8-monochloroBODIPY $\mathbf{1 b}$ was obtained as a minor product from the reaction, in $6 \%$ yield.

The structures of BODIPYs 1a,b, dipyrroketones $\mathbf{3}$ and $\mathbf{5}$ and dipyrrin $\mathbf{4}$ were confirmed by ${ }^{1} \mathrm{H},{ }^{13} \mathrm{C}$ NMR spectroscopy, HRMS (ESI-TOF) and, in the case of $\mathbf{1 a}, \mathbf{b}, \mathbf{3}$, and $\mathbf{4}$ also by $\mathrm{X}$-ray crystallography (Figure 2). The structure of 1a has two independent molecules and a disordered chloroform solvent molecule. The two molecules are almost identical with mean deviations from planarity of their 12-atom BODIPY cores of 0.027 and $0.036 \AA$, and a $9.8^{\circ}$ torsional difference in the conformation of the ethyl group. BODIPY $\mathbf{1 b}$ has four independent molecules, and mean deviations of their BODIPY cores are in the range of 0.023-0.054 A. As in BODIPY 1a, the conformations of the ethyl groups are essentially perpendicular to the BODIPY planes, with C-C-C-C torsion angles differing from $90^{\circ}$ by $0.3-1.7^{\circ}$.

The conformation of dipyrroketone $\mathbf{3}$ is such that one pyrrole NH group is syn to the central carbonyl (N-C-C-O torsion angle $15.5^{\circ}$ ), while the other is syn to the benzyl ester carbonyl (torsion angle $6.0^{\circ}$ ). Both form intermolecular hydrogen bond dimers. On the other hand, dipyrrin 4 is the hydrochloride salt, with both $\mathrm{N}$ atoms protonated, forming hydrogen bonds to the chloride. The $\mathrm{C}_{9} \mathrm{~N}_{2}$ dipyrryl group is planar to within a mean deviation of $0.017 \AA$.

Previous work has shown that symmetric 8 -chloro-- ${ }^{[16]} 3,5$-dichloro- ${ }^{[18 c, d]}$, and 3,5,8trichloro-BODIPYs ${ }^{[20]}$ undergo $\mathrm{Pd}^{0}$-catalyzed cross-coupling reactions, including Suzuki, Sonogashira, Heck, and Stille reactions to produce the corresponding aryl-, alkyl-, alkenyland alkynyl-BODIPYs. Among these, the mild Stille cross-couplings generally give high yields of the targeted functionalized BODIPYs. Under similar conditions, BODIPY 1a reacted in the presence of one or three equivalents of aryltin reagent and $10 \mathrm{~mol} \%$ of $\left[\mathrm{Pd}\left(\mathrm{PPh}_{3}\right)_{4}\right]$ in toluene, to produce the corresponding 8-aryl-3-chloro- and 3,8-diaryl- 
BODIPYs, as shown in Scheme 2. The 3,8-diaryl-BODIPYs 6a-c were produced in 63-86\% yields when an excess of organotin reagent was used, whereas the reaction occurred regioselectively at the most reactive 8-chloride when only one equivalent of organotin was used in a twice diluted solution (ca. $10^{-3} \mathrm{M}$ ) to produce BODIPYs $7 \mathbf{a}-\mathbf{c}$ in $77-84 \%$ yields.

The regioselectivity of these Stille reactions was confirmed by X-ray crystallography, as shown in Figure 3. Crystals of BODIPYs 6a-c and 7c were grown from slow diffusion of hexane into a solution of BODIPY in dichloromethane. Except for BODIPY 7c, all structures exhibit disorder, with the thiophene at the 8-position in 6a having two conformations, as do both furans in $\mathbf{6 b}$ and the ethyl group in $\mathbf{6 c}$. Mean deviations from planarity of the $\mathrm{C}_{9} \mathrm{BN}_{2}$ BODIPY cores are $0.072 \AA$ for $\mathbf{6 a}, 0.087$ for $\mathbf{6 b}, 0.054$ for $\mathbf{6 c}$, and $0.013 \AA$ for $7 \mathbf{c}$. The substituents at the 8-positions deviate by varying amounts from being perpendicular to the BODIPY cores, forming dihedral angles of $87.7^{\circ}$ for $6 \mathbf{a}, 83.0^{\circ}$ for $\mathbf{6 b}$, $79.7^{\circ}$ for $\mathbf{6 c}$, and $75.6^{\circ}$ for $\mathbf{7 c}$, to minimize steric interactions with the 1,7 -methyl groups. On the other hand, the aryl substituents at the 3-position deviate much more from orthogonality with the BODIPY core, forming dihedral angles of $41.7^{\circ}$ for the thiophene in $\mathbf{6 a}, 36.9^{\circ}$ for the furan in $\mathbf{6 b}$, and $42.7^{\circ}$ for the phenyl group in $\mathbf{6 c}$.

We took advantage of the regioselectivity observed in the Stille cross-coupling reactions to prepare BODIPYs 8-10 containing two different aryl groups at the 3- and 8-positions, by performing two consecutive Stille couplings using two different organotin reagents (Scheme 3). Therefore, BODIPY 1a reacted with one equivalent of either 2-(tributylstannyl)thiophene or 2-(tributylstannyl)furan under Stille conditions to pro- duce the 3-monochloro-BODIPYs 7a and $\mathbf{7 b}$ respectively; these BODIPYs were subjected to a second Stille coupling with a different organotin producing BODIPYs $\mathbf{8 - 1 0}$ in $\mathbf{5 8 - 9 1 \%}$ yields. While BODIPY 7a bearing a 8-thienyl group readily reacted with 2-(tributylstannyl)furan producing 8 in high yield, BODIPY $7 \mathbf{b}$ reacted slower and required three equivalents of organotin and a more concentrated reaction mixture (ca. $10^{-2} \mathrm{M}$ ) to produce BODIPYs $\mathbf{9}$ and $\mathbf{1 0}$ in moderate to high yields.

Crystals suitable for X-ray analysis were obtained for all three BODIPYs 8-10 and their structures are shown in Figure 4. In BODIPY 8, both the furan and thiophene rings exhibit rotational disorder. In these three structures, the planarity of the BODIPY core and the dihedral angles formed by the planar substituents at the 3- and 8-positions closely resemble the features in compounds $\mathbf{6 a}-\mathbf{c}$ and $\mathbf{7 c}$. Mean deviations for the $\mathrm{C}_{9} \mathrm{BN}_{2}$ cores are $0.082 \AA$ for 8, $0.071 \AA$ for $\mathbf{9}$, and $0.018 \AA$ for 10. In BODIPY 8, the thiophene at the 8-position forms an $87.2^{\circ}$ angle with the core, and the 8 -furyl groups form slightly lower corresponding dihedral angles of $84.8^{\circ}$ in 9 and $78.0^{\circ}$ in $\mathbf{1 0}$. On the other hand the 3-furyl forms a dihedral angle of $38.6^{\circ}$ with the BODIPY core plane in $\mathbf{8}$, and the 3-thienyl forms an angle of $39.6^{\circ}$ in 9.

Nucleophilic addition/elimination reactions of BODIPY 1a were also investigated using N-, $\mathrm{O}-$, and S-centered nucleophiles, as shown in Scheme 4. Such reactions have been previously reported on 8-chloro-BODIPYs, ${ }^{[16 a, b]}$ and on 3,5-dichloro-BODIPYs, ${ }^{[18 a, b]}$ although the regioselectivity (i.e. meso vs. a-pyrrolic position) of these reactions has never been investigated. BODIPY 1a reacted at room temperature, in the presence of potassium 
carbonate, with up to 10 equivalents of either phenol or aniline as the nucleophile, regioselectively affording the 3-chloro-BODIPYs $\mathbf{1 1}$ and 12, respectively, in high yields (87-95\%). Similar conditions but using $p$-methylthiophenol as the nucleophile produced both the mono- and disubstituted products, showing the higher reactivity of the sulphurcentered nucleophile in these reactions. When 10 equivalents of $p$-methylthiophenol were used, the disubstituted product $\mathbf{1 3}$ was the major product, isolated in $93 \%$ yield. With 1.5 equivalents of thiol, the nucleophilic substitution reaction proceeded with regioselectivity at only the meso-position. These results illustrate the higher reactivity of the 8-chloro versus the 3-chloro group towards nucleophilic reactions.

$\mathrm{X}$-ray crystallography confirmed the regioselectivity of these reactions; Figure 5 shows the structures of BODIPYs 11 and 12. In both, there is a disorder in which the methyl and chloro substituents at the 3- and 5-positions are swapped, the minor component being present with about $8 \%$ population in both cases. Mean deviations from coplanarity of the $\mathrm{C}_{9} \mathrm{BN}_{2}$ core atoms are $0.033 \AA$ for $\mathbf{1 1}$ and $0.061 \AA$ for 12. Interestingly, the plane of the 8phenoxy group forms a dihedral angle of $86.7^{\circ}$ with the BODIPY core in 11, whereas the aniline plane forms an angle of $68.6^{\circ}$ with the core in $\mathbf{1 2}$.

Additionally, we investigated sucessive Stille cross-coupling followed by nucleophilic substitution reactions, and vice-versa, of BODIPY 1a, as shown in Scheme 5. Using this approach and using similar conditions as described above for the two types of reactions, BODIPYs 14 and 15 were synthesized in 67 and 91\% overall yields, respectively. The first reaction always occurs regioselectively at the most reactive 8 -chloro, followed by the second reaction at the 3-chloro group.

The X-ray structure for BODIPY $\mathbf{1 4}$ was also obtained to confirm the regioselectivity of these reactions, and it is shown in Figure 5. The BODIPY core atoms are coplanar to within a mean deviation of $0.019 \AA$, and it forms a dihedral angle of $77.9^{\circ}$ with the 8-phenyl group plane.

The 5-methyl group of BODIPY 1a was unreactive under the Stille cross-coupling and nucleophilic addition/elimination reactions described above. However, it is known that the a-methyl groups of BODIPYs can react with aldehydes under Knoevenagel condensation conditions, ${ }^{[17]}$ providing an additional reactive site for functionalization of BODIPY 1a. Furthermore, we anticipated that this methyl group could be regioselectively oxidized under mild conditions, providing functionality for further derivatization and/or conjugation of the BODIPY. ${ }^{[25]}$ To illustrate these reactions, BODIPY $\mathbf{6 c}$ reacted with 4-formylanisole in the presence of $p$-toluenesulfonic acid and piperidine, in refluxing toluene for $72 \mathrm{~h}$, regioselectively affording monostyryl-BODIPY 16 in 52\% yield (Scheme 6). The monostyryl-BODIPY displays further redshifted absorbance and emission spectra (see below, Table 1 and Figure 7) and potential applications as a fluorescent sensor and photosensitizer. ${ }^{[17]}$

The 3-methyl group of BODIPY $\mathbf{6 c}$ was also regioselectively oxidized in the presence of $\mathrm{DDQ}^{[26]}$ giving formyl-BODIPY $\mathbf{1 7}$ in $26 \%$ yield. Formyl-BODIPYs are useful materials with potential applications as fluorescent sensors, ${ }^{[27]}$ and have been shown to undergo 
Wittig reactions with alkyl or aryl ylides, ${ }^{[28 \mathrm{a}]}$ as well as condensations with malononitrile, methyl acetoacetate, ${ }^{[28 \mathrm{~b}]}$ and pyrrole ${ }^{[28 \mathrm{c}]}$ to produce further functionalized compounds.

BODIPYs 16 and 17 were characterized by X-ray crystallography, as shown in Figure 6. BODIPY 16 crystallizes with two independent molecules in the asymmetric unit, and $\mathbf{1 7}$ as the chloroform solvate. In 16, the BODIPY core atoms of the two molecules have mean deviations of 0.064 and $0.078 \AA$ from co-planarity. The 8-phenyl group forms dihedral angles of 84.0 and $75.0^{\circ}$ with the BODIPY core, the 3-phenyl group forms dihedral angles of 59.8 and $65.9^{\circ}$ with the BODIPY core, and the styryl group forms angles of 26.2 and $22.7^{\circ}$ with the BODIPY core. In BODIPY 17 , the core atoms have mean deviation of 0.075 $\AA$ from coplanarity, the 8-phenyl group forms a dihedral angle of $72.7^{\circ}$ with the BODIPY core and the formyl $\mathrm{C}-\mathrm{C}=\mathrm{O}$ group forms a small dihedral angle of $6.2^{\circ}$ with the BODIPY core.

\section{Spectroscopic properties}

The spectroscopic properties of BODIPYs 1, 6a-c, 7a-c, and 8-17 in dichloromethane, namely their maximum absorption and fluorescence wavelengths, Stokes shifts, molar extinction coefficients and fluorescence quantum yields, are summarized in Table 1. Figure 7 shows the normalized absorption and fluorescence spectra of four representative BODIPYs (see the Supporting Information for additional BODIPY spectra). The BODIPYs have characteristic absorption and emission spectra, showing high molar absorption coefficients ( $\log \varepsilon=4.22-4.95)$ and Stokes-shifted fluorescence emission bands. Relative to BODIPY 1a bearing 3,8-chloro groups, slight blueshifts $(1-5 \mathrm{~nm})$ were observed in the absorption and emission bands of BODIPYs 7c and $\mathbf{1 4}$ bearing 8-phenyl groups, due to the large dihedral angles between this group and the BODIPY core (see Figures 3 and 5) as a result of 1,7-dimethyl substitution. ${ }^{[20]}$ Larger blue-shifts were observed as a result from 8phenoxy and 8-phenylamino substitution, as previously observed for 8-aryloxy and 8arylamino-BODIPYs. ${ }^{[16,29]}$ This is in part due to the destabilization of the LUMO as a result of the electron-donating effect of these groups, which increases the HOMO-LUMO gap. However in contrast, the 8-phenoxy-BODIPY 11 showed a high fluorescence quantum yield ( $\Phi_{\mathrm{f}}=0.89$ ), whereas the 8-phenylamino analogue 12 was practically nonfluorescent $\left(\Phi_{\mathrm{f}}<0.002\right)$, probably due to intramolecular charge transfer in the excited state. The largest quantum yield was observed for the 8-phenoxy-BODIPY 15, bearing a 5-thienyl group $\left(\Phi_{\mathrm{f}}=0.94\right)$. On the other hand, substitution at the 8-position with an arylthio group, as in BODIPY 13, induced a low quantum yield ( $\Phi_{\mathrm{f}}=0.13$ ), as previously observed. ${ }^{[16,29,30]}$

The introduction of 8-thienyl and 8-furyl groups into the BODIPY core caused redshifts in the absorption and emission bands relative to BODIPY 1a, particularly for the furan group, due to a decrease in the HOMO-LUMO gap. The largest redshifts in the 3,8-diarylBODIPYs were induced by furan groups at the 3-position, as in BODIPYs $6 \mathbf{6}$ and $\mathbf{8}$. However, these compounds show low fluorescence quantum yields $\left(\Phi_{\mathrm{f}}<0.1\right)$, as a result of the greater freedom of rotation of the thienyl and furyl groups in comparison with phenyl, which increases the amount of energy lost to nonradiative decay to the ground state. ${ }^{[20,31]}$

The monostyryl-BODIPY 16 showed the most redshifted fluorescence emission $\left(\lambda_{\max }=617\right.$ $\mathrm{nm})$ of all the BODIPYs investigated, and a high quantum yield $\left(\Phi_{\mathrm{f}}=0.73\right)$. On the other 
hand, the significant redshift in the absorption and emission of formyl-BODIPY 17 relative to $\mathbf{6 c}$ is due to the conjugation of the carbonyl group with the BODIPY $\pi$-system, as indicated by the nearly co-planarity seen in the X-ray structure (Figure 6). The lower quantum yield determined for $\mathbf{1 7}$ relative to $\mathbf{6 c}$ is in agreement with previous reports. ${ }^{[26]}$

The Stokes shifts of the 3-, 5-, and/or 8-substituted BODIPYs were generally larger than that of the starting BODIPY 1a, and they were the largest for the 5-thienyl-BODIPYs 6a and $\mathbf{1 5}$ (44 and $49 \mathrm{~nm}$, respectively), in agreement with previous studies, probably due to increased geometry relaxation upon photoexcitation of these compounds. ${ }^{[20,32]}$ The 8-phenylaminoBODIPY 12 also showed larger Stokes shift $(44 \mathrm{~nm})$ than other functionalized BODIPYs, in agreement with previous investigations. ${ }^{[29]}$

\section{Conclusion}

The total synthesis of 3,8-dichloro-6-ethyl-1,2,5,7-tetramethyl-BODIPY 1a from an unsymmetric dipyrroketone was accomplished in good yield. BODIPY 1a undergoes four types of reactions: nucleophilic addition/elimination using $\mathrm{N}-, \mathrm{O}-$, and S-centered nucleophiles and Stille cross-coupling reactions at the 3-and 8-chloro groups, as well as Knoevenagel condensation and oxidation at the most reactive 5-methyl group. Excellent selectivity for the meso-8- over the 3-chloro group of 1a was observed using both nucleophilic and Stille coupling reactions. This regioselectivity is likely the result of the higher electrophilicity of the meso-position versus the a-pyrrolic position based on consideration of mesomeric resonance structures, and of the different mechanistic pathways: $\mathrm{S}_{\mathrm{N}} \mathrm{Ar}$ for a-pyrrolic and addition/elimination for the meso-position. X-ray crystallography (16 structures were obtained) was used to confirm the regioselectivity of the reactions.

The BODIPYs with 8-phenyl, 8-phenoxy, and 8-phenylamino groups showed blueshifted absorption and emission bands relative to BODIPY 1a. All other BODIPYs displayed redshifted bands, with the monostyryl-BODIPY 16 showing the most redshifted absorption and emission of all BODIPYs. The Stokes shifts varied between 15-49 nm, with the 5thienyl-8-phenoxy-BODIPY 15 showing the largest Stokes shift, and also the highest fluorescence quantum yield. In contrast to the phenyl- and phenoxy-substitued BODIPYs, the compounds bearing phenylamino, methylphenylthio, thienyl, and furyl groups at the 8position of the BODIPY core showed very low fluorescence.

\section{Experimental Section}

\section{Syntheses}

General-All reagents and solvents were purchased from Sigma-Aldrich, Fisher Scientific or Alfa Aesar as reagent grade and used without further purification. Argon was used to protect the air-sensitive reactions. Analytical TLC (polyester backed, $60 \AA, 0.2 \mathrm{~mm}$, precoated, Sorbent Technologies) was used to monitor the reactions. Column chromatography was performed on silica gel (60 A, 230-400 mesh, Sorbent Technologies). All ${ }^{1} \mathrm{H}$ and ${ }^{13} \mathrm{C}$ NMR spectra were obtained using Bruker AV-400 nanobay or AV-500 spectrometers (400 or $500 \mathrm{MHz}$ for ${ }^{1} \mathrm{H}$ and $100 \mathrm{MHz}$ for ${ }^{13} \mathrm{C} \mathrm{NMR}$, and $128 \mathrm{MHz}$ for ${ }^{11} \mathrm{~B}$ $\mathrm{NMR}$ spectra) in $\mathrm{CDCl}_{3}$ with tetramethylsilane as an internal standard, at room temperature. 
Chemical shifts $(\delta)$ are given in parts per million (ppm) versus $\mathrm{CDCl}_{3}\left(7.27 \mathrm{ppm}\right.$ for ${ }^{1} \mathrm{H}$ NMR, 77.0 ppm for ${ }^{13} \mathrm{C}$ NMR). All high-resolution mass spectra (ESI-TOF) were obtained using a 6210 ESI-TOF mass spectrometer (Agilent Technologies). All UV/Vis spectra were recorded on a Varian Cary 50 spectrophotometer at room temperature. Fluorescence spectra were studied on a PTI QuantaMaster4/2006SE spectrofluorimeter with the slit width set at 3 $\mathrm{nm}$ at room temperature. A $10 \mathrm{~mm}$ path length quartz cuvette and spectroscopic grade solvents were used for the measurements. The determination of optical density $(\varepsilon)$ was used for the solutions with an absorbance of $\lambda_{\max }$ between $0.5-1$. The dilute solutions with absorbance of particular excitation wavelength between $0.02-0.05$ were used for fluorescence quantum yield measurements. Rhodamine $6 \mathrm{G}(0.95$ in ethanol), rhodamine $\mathrm{B}$ ( 0.49 in ethanol) and crystal violet perchlorate ( 0.54 in methanol) were used as external standards for calculation of the relative fluorescence quantum yields of the BODIPYs. All fluorescence quantum yields $\left(\Phi_{\mathrm{f}}\right.$ ) were determined using the following equation: ${ }^{[33]}$

$$
\Phi_{\mathrm{x}}=\Phi_{\mathrm{S}} \times\left(F_{\mathrm{x}} / F_{\mathrm{s}}\right) \times\left(A_{\mathrm{s}} / A_{\mathrm{x}}\right) \times\left(n_{\mathrm{x}} / n_{\mathrm{s}}\right)^{2}
$$

in which $\Phi_{\mathrm{x}}$ and $\Phi_{\mathrm{S}}$ are the fluorescence quantum yields of the test samples and standards; $F_{\mathrm{X}}$ and $F_{\mathrm{S}}$ are the areas under the test samples' and standards' emission peaks; $A_{\mathrm{X}}$ is the absorbance at which test samples were excited; $A_{\mathrm{S}}$ the absorbance at which standards were excited; $n_{\mathrm{x}}$ and $n_{s}$ are refractive indexes of test samples and standards.

\section{5-Benzyloxycarbonyl-3,4-dimethylpyrrole-2-carboxylic acid (2b): Benzyl-3,4,5-} trimethylpyrrole-2-carboxylate (2a) ${ }^{[21]}(4.34 \mathrm{~g}, 17.84 \mathrm{mmol})$ was dissolved in carbon tetrachloride $(270 \mathrm{~mL})$. Sulfuryl chloride $(7.69 \mathrm{~g}, 57 \mathrm{mmol})$ was added dropwise and the resulting solution was stirred overnight at room temperature. The reaction was stopped when the signals for $\mathrm{RCH}_{2} \mathrm{Cl}(\delta=4.6 \mathrm{ppm})$ and $\mathrm{CHCl}_{2}(\delta=6.7 \mathrm{ppm})$ disappeared from the ${ }^{1} \mathrm{H}$ NMR spectra measured in $\mathrm{CCl}_{4}$. Organic solvents were removed under reduced pressure to give a red oil residue. The oil residue was dissolved in dioxane $(70 \mathrm{~mL})$ and a solution of sodium acetate $(11 \mathrm{~g})$ in water $(60 \mathrm{~mL})$ was added. The solution was stirred at $60-65^{\circ} \mathrm{C}$ for $3 \mathrm{~h}$. The solution was then cooled to room temperature and extracted using diethyl ether $(2 \times 70 \mathrm{~mL})$. The organic layers were combined and washed with $5 \% \mathrm{Na}_{2} \mathrm{CO}_{3}$ aqueous solution. All the aqueous layers were then combined and acidified by slowly adding acetic acid (10\%). A white precipitate was filtered and washed thoroughly with water. The solid was redissovled in THF and dried over anhydrous $\mathrm{Na}_{2} \mathrm{SO}_{4}$. The organic solvents were removed under reduced pressure to give the title product $(3.64 \mathrm{~g})$ in $74.7 \%$ yield. ${ }^{1} \mathrm{H} \mathrm{NMR}\left(\mathrm{CDCl}_{3}, 400\right.$ MHz): $\delta=9.48(1 \mathrm{H}, \mathrm{s}), 7.40-7.44(5 \mathrm{H}, \mathrm{m}), 5.36(2 \mathrm{H}, \mathrm{s}), 2.30 \mathrm{ppm}(6 \mathrm{H}, \mathrm{s}) ;{ }^{13} \mathrm{C} \mathrm{NMR}$ $\left(\mathrm{CDCl}_{3}, 100 \mathrm{MHz}\right): \delta=165.7,160.7,135.7,129.2,128.7,128.4,128.3,127.7,122.5,120.8$, 66.5, $10.1 \mathrm{ppm}$; MS (ESI-TOF) $\mathrm{m} / \mathrm{z}$ : calcd for $\mathrm{C}_{15} \mathrm{H}_{16} \mathrm{NO}_{4}$ : 274.1074; found: 274.1076 [M $+\mathrm{H}]^{+}$.

Benzyl 5-N,N-dimethylamido-3,4-dimethylpyrrole-2-carboxylate (2c): 5Benzyloxycarbonyl-3,4-dimethylpyrrole-2-carboxylic acid (2b) (4.6 g, $16.8 \mathrm{~mol})$ was added portionwise into thionyl chloride $(65 \mathrm{~mL})$ over $20 \mathrm{~min}$. The mixture was stirred for $30 \mathrm{~min}$ at $40-45^{\circ} \mathrm{C}$. The solvent was removed under reduced pressure to give an oily product. The 
oily residue was redissolved in anhydrous benzene $(130 \mathrm{~mL})$. Then, dimethylamine gas was passed into the mixture for $10 \mathrm{~min}$, and the mixture was stirred for another $2 \mathrm{~h}$. The reaction was monitored by TLC analysis. After the reaction was completed, the organic solution was washed with water $(100 \mathrm{~mL})$, dilute acetic acid $(10 \%)$, and water again $(100 \mathrm{~mL})$, and then dried over anhydrous $\mathrm{Na}_{2} \mathrm{SO}_{4}$. The organic solvents were removed under reduced pressure to give a yellow oil. Purification by silica gel column chromatography with $\mathrm{CH}_{2} \mathrm{Cl}_{2} / \mathrm{MeOH}$ as the eluent gave the yellow titled product $(4.3 \mathrm{~g}, 85.1 \%) .{ }^{1} \mathrm{H} \mathrm{NMR}:\left(\mathrm{CDCl}_{3}, 400 \mathrm{MHz}\right)$ : $\delta=9.05(1 \mathrm{H}, \mathrm{s}), 7.34-7.42(5 \mathrm{H}, \mathrm{m}), 5.31(2 \mathrm{H}, \mathrm{s}), 3.06(6 \mathrm{H}, \mathrm{s}), 2.28(3 \mathrm{H}, \mathrm{s}), 2.04 \mathrm{ppm}$ (3 $\mathrm{H}, \mathrm{s}) ;{ }^{13} \mathrm{C} \mathrm{NMR}\left(\mathrm{CDCl}_{3}, 100 \mathrm{MHz}\right): \delta=164.7,160.9,136.1,128.6,128.2,127.2,126.3$, 120.6, 119.8, 66.0, 10.3, 10.3 ppm; MS (ESI-TOF): $m / z$ : calcd for $\mathrm{C}_{17} \mathrm{H}_{21} \mathrm{~N}_{2} \mathrm{O}_{3:}$ 301.1547; found: $301.1548[M+\mathrm{H}]^{+}$.

Benzyl 8-ethyl-2,3,7,9-tetramethyl-5-dipyrroketone-1-carboxylate (3): Benzyl 5- $N, N$ dimethylamido-3,4-dimethylpyrrole-2-carboxylate (2c) (1.808 g, $6.02 \mathrm{mmol})$ was dissolved in warm $\mathrm{POCl}_{3}(9.23 \mathrm{~g}, 60.2 \mathrm{mmol})$ The mixture was stirred at $50^{\circ} \mathrm{C}$ for $5 \mathrm{~h}$ and then cooled to room temperature. Excess $\mathrm{POCl}_{3}$ was removed by evaporation using a ethylene dibromide under reduced pressure to give a red oily product that was then redissolved in $\mathrm{CH}_{2} \mathrm{Cl}_{2}$ (4 $\mathrm{mL})$. A solution of 3-ethyl-2,4-dimethylpyrrole $(0.82 \mathrm{~mL}, 6.02 \mathrm{mmol})$ in $\mathrm{CH}_{2} \mathrm{Cl}_{2}(4 \mathrm{~mL})$ was added into the mixture under argon. The mixture was then stirred at $30^{\circ} \mathrm{C}$ overnight. The reaction was monitored by UV/Vis (reaction was stopped when extinctions at 351/399 $\mathrm{nm}$ reached a maximum). A solution of sodium acetate $(10 \mathrm{~g})$ in water $(25 \mathrm{~mL})$ was added into the mixture, which was then refluxed for $2-3 \mathrm{~h}$. After the mixture was cooled to room temperature, chloroform $(50 \mathrm{~mL} \times 3)$ was used to extract the organic components, which were washed with water, aqueous $\mathrm{Na}_{2} \mathrm{CO}_{3}$ solution (10\%), water again, and finally dried over anhydrous $\mathrm{Na}_{2} \mathrm{SO}_{4}$. The organic solvents were removed under reduced pressure and then the residue was crystallized from $\mathrm{Et}_{2} \mathrm{O}$. Further purification by silica gel chromatography $\left(\mathrm{CH}_{2} \mathrm{Cl}_{2} / \mathrm{MeOH}\right.$ as the eluent) gave a pale yellow product $(1.95 \mathrm{~g})$, in $85.7 \%$ yield. ${ }^{1} \mathrm{H}$ NMR $\left(\mathrm{CDCl}_{3}, 400 \mathrm{MHz}\right): \delta=9.20(1 \mathrm{H}, \mathrm{s}), 8.78(1 \mathrm{H}, \mathrm{s}), 7.35-7.44(5 \mathrm{H}$, m), $5.33(2 \mathrm{H}, \mathrm{s}), 2.38-2.42\left(2 \mathrm{H}, \mathrm{q},{ }^{3} J_{(\mathrm{H}, \mathrm{H})}=7.6 \mathrm{~Hz}\right), 2.36(3 \mathrm{H}, \mathrm{s}), 2.31(3 \mathrm{H}, \mathrm{s}), 2.25(3 \mathrm{H}$, s), $2.15(3 \mathrm{H}, \mathrm{s}), 1.04-1.08 \mathrm{ppm}\left(3 \mathrm{H}, \mathrm{t},{ }^{3} J_{(\mathrm{H}, \mathrm{H})}=7.5 \mathrm{~Hz}\right) ;{ }^{13} \mathrm{C} \mathrm{NMR}\left(\mathrm{CDCl}_{3}, 100 \mathrm{MHz}\right)$ : $\delta=175.6,161.2,136.0,133.0,131.4,128.6,128.3,128.2,127.8,127.7,127.4,125.4,124.3$, 120.4, 66.1 17.3, 15.0, 11.5, 10.8, 10.3, $9.9 \mathrm{ppm}$; MS (ESI-TOF): $\mathrm{m} / \mathrm{z}$ : calcd for $\mathrm{C}_{23} \mathrm{H}_{27} \mathrm{~N}_{2} \mathrm{O}_{3}$ : 379.2016 : found: $379.2017[M+\mathrm{H}]^{+}$.

8-Ethyl-1-iodo-2,3,7,9-tetramethyl-5-dipyrroketone (5): $\mathrm{Pd} / \mathrm{C}$ (165 mg, 10\%) was added to a $250 \mathrm{~mL}$ flask equipped with a magnetic stirrer. The flask was evacuated and refilled with THF (10 mL) and then with $\mathrm{H}_{2}$. The mixture was stirred strongly for 15 min under a $\mathrm{H}_{2}$ atmosphere. A THF $(150 \mathrm{~mL})$ solution of dipyrroketone $\mathbf{3}(1.65 \mathrm{~g}, 4.36 \mathrm{mmol})$ was added to the flask under $\mathrm{H}_{2}$. The mixture was stirred at room temperature for $12 \mathrm{~h}$. The reaction was stopped when the starting material disappeared according to TLC analysis. The palladium catalyst was filtered through a celite cake and washed with THF $(100 \mathrm{~mL} \times 3)$. The organic solutions were combined and the solvents were removed under reduced pressure to yield a white solid. The solid products were dissolved in a mixture of $\mathrm{NaHCO}_{3}(1.87 \mathrm{~g}, 22.3$ $\mathrm{mmol}) / \mathrm{H}_{2} \mathrm{O}(110 \mathrm{~mL})$ and $\mathrm{MeOH}(44 \mathrm{~mL})$. A solution of $\mathrm{I}_{2}(1.63 \mathrm{~g}, 6.42 \mathrm{mmol})$ in $\mathrm{MeOH}$ $(26 \mathrm{~mL})$ was added dropwise into the mixture at room temperature and brown solids 
precipitated out immediately. The mixture was stirred for another $2 \mathrm{~h}$ at room temperature after the addition was completed. The solids were filtered and washed with water, saturated $\mathrm{NaHCO}_{3}(\mathrm{aq})$, water again, and hexanes to remove excess iodine. The solids were redissolved in $\mathrm{CH}_{2} \mathrm{Cl}_{2}$ and dried over anhydrous $\mathrm{Na}_{2} \mathrm{SO}_{4}$. The organic solvents were removed under reduced pressure to give a pure pale yellow product $(1.36 \mathrm{~g}, 84.2 \%) .{ }^{1} \mathrm{H}$ NMR: $\left(\mathrm{CDCl}_{3}, 400 \mathrm{MHz}\right): \delta=8.79(1 \mathrm{H}, \mathrm{s}), 8.64(1 \mathrm{H}, \mathrm{s}), 2.38-2.43\left(2 \mathrm{H}, \mathrm{q},{ }^{3} J_{(\mathrm{H}, \mathrm{H})}=6.9\right.$ $\mathrm{Hz}), 2.45(3 \mathrm{H}, \mathrm{s}), 2.17(3 \mathrm{H}, \mathrm{s}), 2.13(3 \mathrm{H}, \mathrm{s}), 2.00(3 \mathrm{H}, \mathrm{s}), 1.06-1.10 \mathrm{ppm}(3 \mathrm{H}$, t, $\left.{ }^{3} J_{(\mathrm{H}, \mathrm{H})}=6.8 \mathrm{~Hz}\right) ;{ }^{13} \mathrm{C} \mathrm{NMR}\left(\mathrm{CDCl}_{3}, 100 \mathrm{MHz}\right): \delta=174.5,133.6,131.1,126.9,126.5$, 126.4 124.9, 124.8, 73.2, 17.3, 15.1, 11.9, 11.5, 11.2, 10.8 ppm; MS (ESI-TOF): $\mathrm{m} / \mathrm{z}$ : calcd for $\mathrm{C}_{15} \mathrm{H}_{20} \mathrm{IN}_{2} \mathrm{O}$ : 371.0615 ; found: $371.0613[M+\mathrm{H}]^{+}$.

3,8-Dichloro-6-ethyl-1,2,5,7-tetramethyl-BODIPY (1a): Iododipyrroketone 5 (1.36 g, $3.67 \mathrm{mmol})$ was dissolved in chloroform $(300 \mathrm{~mL})$. The flask was evacuated and refilled with argon. Phosgene solution (15\% in toluene, $26 \mathrm{~mL}$ ) was added into the mixture and then it was stirred overnight at room temperature. The reaction was stopped when the starting materials were totally consumed. $\mathrm{N}_{2}$ was purged into the flask to remove extra phosgene into a beaker containing saturated $\mathrm{NaHCO}_{3}$ solution. The organic solvents were removed under reduced pressure to obtain a red solid. The red solid was added into another $500 \mathrm{~mL}$ round-bottom flask equipped with a stirrer. The flask was evacuated and refilled with argon. Chloroform $(300 \mathrm{~mL})$ and $N, N$-diisopropylethylamine $(3.32 \mathrm{~g}, 25.7 \mathrm{mmol})$ were added under argon. The mixture was then stirred for $30 \mathrm{~min} . \mathrm{BF}_{3} \cdot \mathrm{OEt}_{2}(5.2 \mathrm{~g}, 36.7 \mathrm{mmol})$ was added into the mixture which was stirred for another $10 \mathrm{~h}$. The organic solution was washed with water, saturated $\mathrm{NaHCO}_{3}$ solution, and brine. After drying over anhydrous $\mathrm{Na}_{2} \mathrm{SO}_{4}$, the organic solvents were removed under reduced pressure. Further purification by silica gel column chromatography with $\mathrm{CH}_{2} \mathrm{Cl}_{2}$ /hexanes as the eluent gave the titled BODIPY 1a $(0.99 \mathrm{~g}, 78.2 \%)$ and its 8-monochloro-BODIPY byproduct $(68 \mathrm{mg}, 6 \%)$.

For BODIPY 1a: ${ }^{1} \mathrm{H}$ NMR $\left(\mathrm{CDCl}_{3}, 400 \mathrm{MHz}\right): \delta=2.54(3 \mathrm{H}, \mathrm{s}), 2.40-2.45(8 \mathrm{H}, \mathrm{m}$, overlapped), 2.01(3 H, s), $1.05-1.09 \mathrm{ppm}\left(3 \mathrm{H}, \mathrm{t},{ }^{3} \mathrm{~J}_{(\mathrm{H}, \mathrm{H})}=7.5 \mathrm{~Hz}\right) ;{ }^{13} \mathrm{C} \mathrm{NMR}\left(\mathrm{CDCl}_{3}, 100\right.$ MHz): $\delta=158.4,140.4,138.2,137.5,135.4,135.2,130.8,127.6,124.5,17.1,14.5,14.2$, 14.1, 12.9, 8.9 ppm; ${ }^{11} \mathrm{~B}$ NMR $\left(\mathrm{CDCl}_{3}, 128 \mathrm{MHz}\right): \delta=0.18 \mathrm{ppm}\left(\mathrm{t},{ }^{1} J_{(\mathrm{B}, \mathrm{F})}=30.2 \mathrm{~Hz}\right) ; \mathrm{MS}$ (ESI-TOF): $m / z$ : calcd for $\mathrm{C}_{15} \mathrm{H}_{17} \mathrm{BCl}_{2} \mathrm{~F}_{2} \mathrm{~N}_{2:}$ 344.0939; $344.0937[M+\mathrm{H}]^{+}$.

For the 8-monochloro-BODIPY byproduct 1 b: ${ }^{1} \mathrm{H}$ NMR $\left(\mathrm{CDCl}_{3}, 400 \mathrm{MHz}\right): \delta=7.40(1 \mathrm{H}$, s), 2.53 (3 H, s), 2.40-2.45 (8 H, m, overlapped), 2.04 (3 H, s), 1.05-1.09 ppm ( $3 \mathrm{H}$, $\left.\mathrm{t},{ }^{3} J_{(\mathrm{H}, \mathrm{H})}=7.5 \mathrm{~Hz}\right) ;{ }^{13} \mathrm{C} \mathrm{NMR}\left(\mathrm{CDCl}_{3}, 400 \mathrm{MHz}\right): \delta=157.8,140.6,138.7,137.5,137.0$,

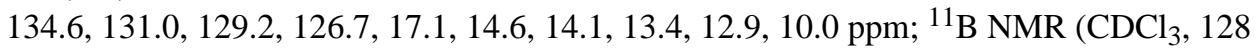
MHz): $\delta=0.05 \mathrm{ppm}\left(\mathrm{t},{ }^{1} J_{(\mathrm{B}, \mathrm{F})}=30.3 \mathrm{~Hz}\right.$ ); MS (ESI-TOF): $\mathrm{m} / z$ : calcd for $\mathrm{C}_{15} \mathrm{H}_{19} \mathrm{BClF}_{2} \mathrm{~N}_{2}$ : 310.1329; found: $310.1307[M+\mathrm{H}]^{+}$.

General procedure for the preparation of BODIPYs 6a-c: Into a $50 \mathrm{~mL}$ round-bottom flask was added 3,8-dichloro-1,2,5,7- tetramethyl-BODIPY $\mathbf{1 a}(34.4 \mathrm{mg}, 0.1 \mathrm{mmol})$ and $\left[\mathrm{Pd}\left(\mathrm{PPh}_{3}\right)_{4}\right](10 \mathrm{~mol} \%)$. The flask was then evacuated and refilled with argon 3 times. Dry toluene $(30 \mathrm{~mL})$ and organostannane regent $(0.3 \mathrm{mmol})$ were introduced into the flask. The mixture was refluxed for $6 \mathrm{~h}$ under an argon atmosphere. The reaction was stopped when 
TLC analysis showed the disappearance of starting material. Toluene was removed under reduced pressure. A flash column chromatography $\left(\mathrm{CH}_{2} \mathrm{Cl}_{2}\right.$ as the eluent) was used to separate the crude products. Further purification by using a silica gel column with $\mathrm{CH}_{2} \mathrm{Cl}_{2}$ / hexanes or ethyl acetate/hexanes as the eluent gave the desired disubstituted BODIPY products.

BODIPY 6a: Yield: $37.7 \mathrm{mg}, 85.6 \%$; ${ }^{1} \mathrm{H}$ NMR $\left(\mathrm{CDCl}_{3}, 400 \mathrm{MHz}\right): \delta=7.50-7.55(3 \mathrm{H}, \mathrm{m})$, 7.02-7.19 (3 H, m), $2.51(3 \mathrm{H}, \mathrm{s}), 2.31-2.36\left(2 \mathrm{H}, \mathrm{q},{ }^{3} J_{(\mathrm{H}, \mathrm{H})}=7.6 \mathrm{~Hz}\right), 1.97(3 \mathrm{H}, \mathrm{s}), 1.53(6$ $\mathrm{H}, \mathrm{s}), 0.99-1.03 \mathrm{ppm}\left(3 \mathrm{H}, \mathrm{t},{ }^{3} J_{(\mathrm{H}, \mathrm{H})}=7.6 \mathrm{~Hz}\right) ;{ }^{13} \mathrm{C} \mathrm{NMR}\left(\mathrm{CDCl}_{3}, 100 \mathrm{MHz}\right): \delta=158.6$, 145.4, 140.4, 138.2, 135.6, 134.9, 133.5, 133.0, 132.8, 132.1, 130.6, 130.5, 128.1, 127.7, 127.7, 127.5, 127.0, 17.1, 14.4, 13.0, 11.3, 11.1, $10.4 \mathrm{ppm} ;{ }^{11} \mathrm{~B}$ NMR $\left(\mathrm{CDCl}_{3}, 128 \mathrm{MHz}\right)$ : $\delta=0.66 \mathrm{ppm}\left(\mathrm{t},{ }^{1} J_{(\mathrm{B}, \mathrm{F})}=32.3 \mathrm{~Hz}\right.$ ); MS (ESI-TOF): $\mathrm{m} / z$ : calcd for $\mathrm{C}_{23} \mathrm{H}_{23} \mathrm{BF}_{2} \mathrm{~N}_{2} \mathrm{~S}_{2}: 440.1473$; found: $440.1445[M+\mathrm{H}]^{+}$.

BODIPY 6b: Yield: $25.8 \mathrm{mg}, 63.2 \%$; ${ }^{1} \mathrm{H} \mathrm{NMR}\left(\mathrm{CDCl}_{3}, 400 \mathrm{MHz}\right): \delta=7.49-7.64(3 \mathrm{H}, \mathrm{m})$, 6.44-6.59 (3 H, m), $2.57(3 \mathrm{H}, \mathrm{s}), 2.32-2.38\left(2 \mathrm{H}, \mathrm{q},{ }^{3} J_{(\mathrm{H}, \mathrm{H})}=7.4 \mathrm{~Hz}\right), 2.17(3 \mathrm{H}, \mathrm{s}), 1.52(3$ $\mathrm{H}, \mathrm{s}), 1.50(3 \mathrm{H}, \mathrm{s}), 1.01-1.05 \mathrm{ppm}\left(3 \mathrm{H}, \mathrm{t},{ }^{3} J_{(\mathrm{H}, \mathrm{H})}=7.4 \mathrm{~Hz}\right) ;{ }^{13} \mathrm{C} \mathrm{NMR}\left(\mathrm{CDCl}_{3}, 100 \mathrm{MHz}\right)$ : $\delta=157.9,147.3,146.0,143.6,142.5,142.4,139.2,138.7,134.4,133.8,133.5,127.7,126.3$, 115.2(t), 112.3, 111.7, 111.5, 17.1, 14.4, 13.0, 10.9, $10.4 \mathrm{ppm} ;{ }^{11} \mathrm{~B} \mathrm{NMR}\left(\mathrm{CDCl}_{3}, 128\right.$ MHz): $\delta=0.87 \mathrm{ppm}\left(\mathrm{t},{ }^{1} J_{(\mathrm{B}, \mathrm{F})}=32.7 \mathrm{~Hz}\right.$ ); MS (ESI-TOF): $\mathrm{m} / z$ : calcd for $\mathrm{C}_{23} \mathrm{H}_{23} \mathrm{BF}_{2} \mathrm{~N}_{2} \mathrm{O}_{2}$ : 408.193; found: $408.1905[M+\mathrm{H}]^{+}$.

BODIPY 6c: Yield: $34.6 \mathrm{mg}, 80.8 \%$; ${ }^{1} \mathrm{H}$ NMR $\left(\mathrm{CDCl}_{3}, 400 \mathrm{MHz}\right): \delta=7.35-7.49(10 \mathrm{H}$, m), $2.46(3 \mathrm{H}, \mathrm{s}), 2.27-2.33\left(2 \mathrm{H}, \mathrm{q},{ }^{3} J_{(\mathrm{H}, \mathrm{H})}=7.4 \mathrm{~Hz}\right), 1.79(3 \mathrm{H}, \mathrm{s}), 1.32(3 \mathrm{H}, \mathrm{s}), 1.35(3 \mathrm{H}$, s), 0.96-0.99 ppm ( $\left.3 \mathrm{H}, \mathrm{t},{ }^{3} J_{(\mathrm{H}, \mathrm{H})}=7.4 \mathrm{~Hz}\right) ;{ }^{13} \mathrm{C} \mathrm{NMR}\left(\mathrm{CDCl}_{3}, 100 \mathrm{MHz}\right): \delta=156.8,153.2$, 141.3, 139.8, 138.2, 135.8, 134.0, 132.9, 131.8, 130.9, 130.0, 129.1, 128.9, 128.4, 128.3,

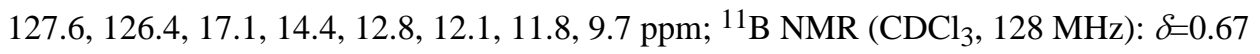
ppm (t, ${ }^{1} J_{(\mathrm{B}, \mathrm{F})}=32.4 \mathrm{~Hz}$ ); MS (ESI-TOF): $\mathrm{m} / z$ : calcd for $\mathrm{C}_{27} \mathrm{H}_{26} \mathrm{BFN}_{2}$ : 408.2282; found: $408.2284[M-\mathrm{F}]^{+}$.

General procedure for the preparation of BODIPYs 7a-c: Into a $100 \mathrm{~mL}$ round-bottom flask was added BODIPY 1a (34.4 mg, $0.1 \mathrm{mmol})$ and $\left[\mathrm{Pd}\left(\mathrm{PPh}_{3}\right)_{4}\right](10 \mathrm{~mol} \%)$. The flask was then evacuated and refilled with argon 3 times. Dry toluene $(60 \mathrm{~mL})$ and organostannane regent $(0.1 \mathrm{mmol})$ were introduced into the flask. The mixture was refluxed at $80^{\circ} \mathrm{C}$ under Ar. The reaction was stopped when TLC analysis showed the disappearance of starting material. Toluene was removed under reduced pressure. Silica gel flash column chromatography was used for purification of the products, eluting with dichloromethane/ hexanes or ethyl acetate/hexanes.

BODIPY 7a: Yield: $33 \mathrm{mg}, 84 \% ;{ }^{1} \mathrm{H}$ NMR $\left(\mathrm{CDCl}_{3}, 400 \mathrm{MHz}\right): \delta=7.52-7.54(1 \mathrm{H}$, q, $\left.{ }^{3} J_{(\mathrm{H}, \mathrm{H})}=4.0,{ }^{4} J_{(\mathrm{H}, \mathrm{H})}=1.1 \mathrm{~Hz}\right), 7.14-7.16\left(1 \mathrm{H}, \mathrm{q},{ }^{3} J_{(\mathrm{H}, \mathrm{H})}=3.5,{ }^{3} J_{(\mathrm{H}, \mathrm{H})}=1.5 \mathrm{~Hz}\right) ; 6.99-7.00$ $\left(1 \mathrm{H}, \mathrm{q},{ }^{3} J_{(\mathrm{H}, \mathrm{H})}=2.3,{ }^{4} J_{(\mathrm{H}, \mathrm{H})}=1.1 \mathrm{~Hz}\right), 2.58(3 \mathrm{H}, \mathrm{s}), 2.31-2.37\left(2 \mathrm{H}, \mathrm{q},{ }^{3} J_{(\mathrm{H}, \mathrm{H})}=7.5 \mathrm{~Hz}\right), 1.92$ $(3 \mathrm{H}, \mathrm{s}), 1.52(3 \mathrm{H}, \mathrm{s}), 1.48(3 \mathrm{H}, \mathrm{s}), 1.00-1.03 \mathrm{ppm}\left(3 \mathrm{H}, \mathrm{t},{ }^{3} J_{(\mathrm{H}, \mathrm{H})}=7.6 \mathrm{~Hz}\right) ;{ }^{13} \mathrm{C} \mathrm{NMR}$ $\left(\mathrm{CDCl}_{3}, 100 \mathrm{MHz}\right): \delta=159.4,141.1,139.0,138.1,135.1,134.8,133.4,132.7,130.2,128.1$, 127.7, 127.6, 124.3, 17.1, 14.3, 13.0, 11.3, 11.1, $8.8 \mathrm{ppm} ;{ }^{11} \mathrm{~B}$ NMR ( $\left.\mathrm{CDCl}_{3}, 128 \mathrm{MHz}\right)$ : 
$\delta=0.35 \mathrm{ppm}\left(\mathrm{t},{ }^{1} J_{(\mathrm{B}, \mathrm{F})}=31.0 \mathrm{~Hz}\right) ; \mathrm{MS}$ (ESI-TOF): $m / z$ : calcd for $\mathrm{C}_{19} \mathrm{H}_{20} \mathrm{BClF}_{2} \mathrm{~N}_{2} \mathrm{~S}$ : 392.1206; found: $392.1208[M+\mathrm{H}]^{+}$.

BODIPY 7b: Yield: $29 \mathrm{mg}, 77 \% ;{ }^{1} \mathrm{H}$ NMR ( $\left.\mathrm{CDCl}_{3}, 400 \mathrm{MHz}\right): 7.63-7.64(1 \mathrm{H}, \mathrm{m}), 6.56-$ $6.57\left(1 \mathrm{H}, \mathrm{q},{ }^{3} J_{(\mathrm{H}, \mathrm{H})}=1.8,{ }^{3} J_{(\mathrm{H}, \mathrm{H})}=1.5 \mathrm{~Hz}\right), 6.45-6.46(1 \mathrm{H}, \mathrm{m}), 2.57(3 \mathrm{H}, \mathrm{s}), 2.32-2.38(2 \mathrm{H}$, q, $\left.{ }^{3} J_{(\mathrm{H}, \mathrm{H})}=7.6 \mathrm{~Hz}\right), 1.93(3 \mathrm{H}, \mathrm{s}), 1.52(3 \mathrm{H}, \mathrm{s}), 1.49(3 \mathrm{H}, \mathrm{s}), 1.01-1.05 \mathrm{ppm}(3 \mathrm{H}$, $\left.\mathrm{t},{ }^{3} J_{(\mathrm{H}, \mathrm{H})}=7.5 \mathrm{~Hz}\right) ;{ }^{13} \mathrm{C} \mathrm{NMR}\left(\mathrm{CDCl}_{3}, 100 \mathrm{MHz}\right): \delta=160.3,145.1,142.8,140.8,139.3$, 137.7, 135.1, 134.1, 130.6, 126.9, 124.3, 111.8, 111.6, 17.1, 14.3, 13.1, 10.8, 10.6, 8.8 ppm; ${ }^{11} \mathrm{~B} \mathrm{NMR}\left(\mathrm{CDCl}_{3}, 128 \mathrm{MHz}\right): \delta=0.32 \mathrm{ppm}\left(\mathrm{t},{ }^{1} J_{(\mathrm{B}, \mathrm{F})}=30.9 \mathrm{~Hz}\right) ; \mathrm{MS}(\mathrm{ESI}-\mathrm{TOF}): \mathrm{m} / \mathrm{z}$ : calcd for $\mathrm{C}_{19} \mathrm{H}_{20} \mathrm{BClF}_{2} \mathrm{~N}_{2} \mathrm{O}: 376.1434$; found: $376.1410[M+\mathrm{H}]^{+}$.

BODIPY 7c: Yield: $32.4 \mathrm{mg}, 83.8 \%$; ${ }^{1} \mathrm{H}$ NMR $\left(\mathrm{CDCl}_{3}, 400 \mathrm{MHz}\right): \delta=7.28-7.50(5 \mathrm{H}, \mathrm{m})$, 2.58(3 H, s), 2.29-2.35 (2 H, q, $\left.{ }^{3} J_{(\mathrm{H}, \mathrm{H})}=7.5 \mathrm{~Hz}\right), 1.90(3 \mathrm{H}, \mathrm{s}), 1.28(3 \mathrm{H}, \mathrm{s}), 1.30(3 \mathrm{H}, \mathrm{s})$, $0.98-1.02 \mathrm{ppm}\left(3 \mathrm{H}, \mathrm{t},{ }^{3} \mathrm{~J}_{(\mathrm{H}, \mathrm{H})}=7.5 \mathrm{~Hz}\right) ;{ }^{13} \mathrm{C} \mathrm{NMR}\left(\mathrm{CDCl}_{3}, 100 \mathrm{MHz}\right): \delta=158.5,140.8$, 140.5, 138.4, 137.9, 135.1, 134.7, 132.2, 129.4, 129.2, 129.1, 128.1, 124.0, 17.1, 14.4, 12.9, 12.1, 11.9, $8.8 \mathrm{ppm} ;{ }^{11} \mathrm{~B}$ NMR $\left(\mathrm{CDCl}_{3}, 128 \mathrm{MHz}\right): \delta=0.41 \mathrm{ppm}\left(\mathrm{t},{ }^{1} J_{(\mathrm{B}, \mathrm{F})}=31.1 \mathrm{~Hz}\right) ; \mathrm{MS}$ (ESI-TOF): $m / z$ : calcd for $\mathrm{C}_{21} \mathrm{H}_{22} \mathrm{BClFN}_{2}: 366.1579 ; 366.1567[M-\mathrm{F}]^{+}$.

BODIPY 8: Into a $50 \mathrm{~mL}$ round-bottom flask was added BODIPY 7a (19.6 mg, $0.05 \mathrm{mmol})$ and $\left[\mathrm{Pd}\left(\mathrm{PPh}_{3}\right)_{4}\right](10 \mathrm{~mol} \%)$. The flask was then evacuated and refilled with argon 3 times. Dry toluene $(20 \mathrm{~mL})$ and tributyl-(2-furyl)stannane $(0.1 \mathrm{mmol})$ were introduced into the flask. The mixture was refluxed for $6 \mathrm{~h}$ under Ar. The reaction was stopped when TLC analysis showed the disappearance of starting materials. Toluene was removed under reduced pressure. A flash column chromatography $\left(\mathrm{CH}_{2} \mathrm{Cl}_{2}\right.$ as the eluent) was used to separate the crude products. Further purification by silica gel column chromatography with ethyl acetate/hexanes as the eluent gave the desired disubstituted BODIPY product. Yield: $19.3 \mathrm{mg}, 91 \%$; ${ }^{1} \mathrm{H} \mathrm{NMR}\left(\mathrm{CDCl}_{3}, 400 \mathrm{MHz}\right): \delta=7.61(1 \mathrm{H}, \mathrm{m}), 7.52-7.53(1 \mathrm{H}, \mathrm{m}), 7.46-$ $7.47(1 \mathrm{H}, \mathrm{m}), 7.15-7.17(1 \mathrm{H}, \mathrm{m}), 7.00-7.01(1 \mathrm{H}, \mathrm{m}), 6.59-6.60(1 \mathrm{H}, \mathrm{m}), 2.57(3 \mathrm{H}, \mathrm{s})$, 2.30-2.37 (2 H, q, $\left.{ }^{3} J_{(\mathrm{H}, \mathrm{H})}=7.4 \mathrm{~Hz}\right), 2.15(3 \mathrm{H}, \mathrm{s}), 1.52(6 \mathrm{H}, \mathrm{s}), 1.00-1.04 \mathrm{ppm}(3 \mathrm{H}$, $\left.\mathrm{t},{ }^{3} J_{(\mathrm{H}, \mathrm{H})}=7.5 \mathrm{~Hz}\right) ;{ }^{13} \mathrm{C} \mathrm{NMR}\left(\mathrm{CDCl}_{3}, 100 \mathrm{MHz}\right): \delta=157.2,147.2,143.5,141.8,139.7$, 139.0, 135.8, 134.5, 133.1, 132.8, 128.2, 127.8, 127.6, 127.4, 114.9 (t), 112.2, 17.1, 14.4, 12.9, 11.1, 11.0, $10.9 \mathrm{ppm} ;{ }^{11} \mathrm{~B} \mathrm{NMR}\left(\mathrm{CDCl}_{3}, 128 \mathrm{MHz}\right): \delta=0.84 \mathrm{ppm}\left(\mathrm{t},{ }^{1} J_{(\mathrm{B}, \mathrm{F})}=32.8 \mathrm{~Hz}\right)$; MS (ESI-TOF): $m / z$ calcd for $\mathrm{C}_{23} \mathrm{H}_{23} \mathrm{BF}_{2} \mathrm{~N}_{2} \mathrm{NaOS}: 446.1521 ; 446.1517[M+\mathrm{Na}]^{+}$.

BODIPY 9: Into a $50 \mathrm{~mL}$ round bottom flask was added BODIPY $\mathbf{7 b}(18.8 \mathrm{mg}, 0.05 \mathrm{mmol})$ and $\left[\mathrm{Pd}\left(\mathrm{PPh}_{3}\right)_{4}\right](10 \mathrm{~mol} \%)$. The flask was then evacuated and refilled with argon for 3 times. Dry toluene $(20 \mathrm{~mL})$ and 2-(tributylstannyl)thiophene $(0.15 \mathrm{mmol})$ were introduced into the flask. The mixture was refluxed for $6 \mathrm{~h}$ under Ar. The reaction was stopped when TLC analysis showed the disappearance of starting material. Toluene was removed under reduced pressure. A flash column chromatography $\left(\mathrm{CH}_{2} \mathrm{Cl}_{2}\right.$ as eluent) was used to give the crude products. Further purification by silica gel column chromatography with ethyl acetate/ hexanes as the eluent gave the desired disubstituted BODIPY product. Yield: $19 \mathrm{mg}$, 89.6\%; ${ }^{1} \mathrm{H} \mathrm{NMR}\left(\mathrm{CDCl}_{3}, 400 \mathrm{MHz}\right): \delta=7.67(1 \mathrm{H}, \mathrm{m}), 7.51-7.56(2 \mathrm{H}, \mathrm{m}), 7.18-7.20(1 \mathrm{H}$, m), $6.59(1 \mathrm{H}, \mathrm{m}), 6.48-6.49(1 \mathrm{H}, \mathrm{m}), 2.51(3 \mathrm{H}, \mathrm{s}), 2.32-2.37\left(2 \mathrm{H}, \mathrm{q},{ }^{3} J_{(\mathrm{H}, \mathrm{H})}=7.6 \mathrm{~Hz}\right)$, $1.99(3 \mathrm{H}, \mathrm{s}), 1.53(6 \mathrm{H}, \mathrm{s}), 1.00-1.04 \mathrm{ppm}\left(3 \mathrm{H}, \mathrm{t},{ }^{3} J_{(\mathrm{H}, \mathrm{H})}=7.5 \mathrm{~Hz}\right) ;{ }^{13} \mathrm{C} \mathrm{NMR}\left(\mathrm{CDCl}_{3}, 100\right.$ 
MHz): $\delta=159.4,146.0,145.8,142.6,140.0,137.9,134.8,134.1,132.8,132.6,130.6(\mathrm{t})$, 127.8, 127.6, 127.1, 127.0, 111.7, 112.5, 17.1, 14.4, 13.1, 10.7, 10.5, $10.4 \mathrm{ppm} ;{ }^{11} \mathrm{~B}$ NMR $\left(\mathrm{CDCl}_{3}, 128 \mathrm{MHz}\right): \delta=0.68 \mathrm{ppm}\left(\mathrm{t},{ }^{1} J_{(\mathrm{B}, \mathrm{F})}=32.2 \mathrm{~Hz}\right.$ ); MS (ESI-TOF): $\mathrm{m} / \mathrm{z}:$ calcd for $\mathrm{C}_{23} \mathrm{H}_{24} \mathrm{BF}_{2} \mathrm{~N}_{2} \mathrm{OS}$ : 424.1701; found: $424.1674[M+\mathrm{H}]^{+}$.

BODIPY 10: Into a $50 \mathrm{~mL}$ round-bottom flask was added meso-substituted BODIPY $7 \mathbf{b}$ $(18.8 \mathrm{mg}, 0.05 \mathrm{mmol})$ and $\left[\mathrm{Pd}\left(\mathrm{PPh}_{3}\right)_{4}\right](10 \mathrm{~mol} \%)$. The flask was then evacuated and refilled with argon 3 times. Dry toluene $(4 \mathrm{~mL})$ and trimethyl[(tributylstannyl)ethynyl]silane $(0.06$ $\mathrm{mmol}$ ) were introduced into the flask. The mixture was refluxed for $6 \mathrm{~h}$ under an argon atmosphere. The reaction was stopped when TLC analysis showed the disappearance of starting material. Toluene was removed under reduced pressure. A flash column chromatography $\left(\mathrm{CH}_{2} \mathrm{Cl}_{2}\right.$ as eluent) was used to separate the crude products. Further purification by silica gel column chromatography with ethyl acetate/hexanes as the eluent gave the desired disubstituted BODIPY product. Yield: $12.7 \mathrm{mg}, 58 \% ;{ }^{1} \mathrm{H} \mathrm{NMR}\left(\mathrm{CDCl}_{3}\right.$, $400 \mathrm{MHz}): \delta=7.62(1 \mathrm{H}, \mathrm{m}), 6.54-6.56\left(1 \mathrm{H}, \mathrm{q},{ }^{3} J_{(\mathrm{H}, \mathrm{H})}=1.7 \mathrm{~Hz},{ }^{3} J_{(\mathrm{H}, \mathrm{H})}=1.5 \mathrm{~Hz}\right), 6.43-6.44$

$(1 \mathrm{H}, \mathrm{m}), 2.59(3 \mathrm{H}, \mathrm{s}), 2.32-2.37\left(2 \mathrm{H}, \mathrm{q},{ }^{3} J_{(\mathrm{H}, \mathrm{H})}=7.5 \mathrm{~Hz}\right), 1.99(3 \mathrm{H}, \mathrm{s}), 1.52(3 \mathrm{H}, \mathrm{s}), 1.45$ $(3 \mathrm{H}, \mathrm{s}), 1.00-1.04\left(3 \mathrm{H}, \mathrm{t},{ }^{3} J_{(\mathrm{H}, \mathrm{H})}=7.5 \mathrm{~Hz}\right), 0.31 \mathrm{ppm}(9 \mathrm{H}, \mathrm{s}) ;{ }^{13} \mathrm{C} \mathrm{NMR}\left(\mathrm{CDCl}_{3}, 100\right.$ MHz): $\delta=162.1,145.8,143.0,141.1,136.3,135.8,132.7,132.6,132.2,126.9,112.0,111.8$, 109.3, 97.3, 17.5, 14.6, 13.7, 10.9, 10.7, 10.0, $0.2 \mathrm{ppm} ;{ }^{11} \mathrm{~B}$ NMR $\left(\mathrm{CDCl}_{3}, 128 \mathrm{MHz}\right)$ : $\delta=0.28 \mathrm{ppm}\left(\mathrm{t},{ }^{1} J_{(\mathrm{B}, \mathrm{F})}=30.0 \mathrm{~Hz}\right) ; \mathrm{MS}$ (ESI-TOF): $\mathrm{m} / z$ : calcd for $\mathrm{C}_{24} \mathrm{H}_{30} \mathrm{BF}_{2} \mathrm{~N}_{2} \mathrm{OSi}$ : 438.2219; found: $438.2223[M+\mathrm{H}]^{+}$.

General procedure for the preparation of BODIPYs 11-13: Into a $5 \mathrm{~mL}$ round-bottom flask was added BODIPY $1 \mathbf{a}(17.2 \mathrm{mg}, 0.05 \mathrm{mmol})$, nucleophile (1-10 equiv), and $\mathrm{K}_{2} \mathrm{CO}_{3}$ (13.8 mg, $0.1 \mathrm{mmol}) . \mathrm{CH}_{2} \mathrm{Cl}_{2}(0.5 \mathrm{~mL})$ was added into the flask. The mixture was stirred at room temperature. The reaction was stopped when TLC analysis showed the disappearance of starting material. The crude product was subjected to a short flash column chromatography $\left(\mathrm{CH}_{2} \mathrm{Cl}_{2}\right.$ as eluents) to remove polar byproducts. Further purification by silica gel column chromatography with $\mathrm{CH}_{2} \mathrm{Cl}_{2}$ /hexanes or ethyl acetate/hexanes as the eluent gave the desired BODIPY products.

BODIPY 11: Yield: $19.1 \mathrm{mg}, 94.9 \%$; ${ }^{1} \mathrm{H}$ NMR $\left(\mathrm{CDCl}_{3}, 400 \mathrm{MHz}\right): \delta=6.99-7.34(5 \mathrm{H}, \mathrm{m})$, $2.57(3 \mathrm{H}, \mathrm{s}), 2.34-2.38\left(2 \mathrm{H}, \mathrm{q},{ }^{3} J_{(\mathrm{H}, \mathrm{H})}=7.1 \mathrm{~Hz}\right), 2.01(3 \mathrm{H}, \mathrm{s}), 1.98(3 \mathrm{H}, \mathrm{s}), 1.93(3 \mathrm{H}, \mathrm{s})$, 1.01-1.04 ppm ( $\left.3 \mathrm{H}, \mathrm{t},{ }^{3} J_{(\mathrm{H}, \mathrm{H})}=7.3 \mathrm{~Hz}\right) ;{ }^{13} \mathrm{C}$ NMR $\left(\mathrm{CDCl}_{3}, 100 \mathrm{MHz}\right): \delta=158.6,157.5$, 150.5, 138.2, 137.8, 135.2, 133.9, 130.5, 128.3, 125.6, 123.5, 123.0, 114.7, 16.9, 14.4, 13.0, 12.0, 11.7, $8.6 \mathrm{ppm} ;{ }^{11} \mathrm{~B} \mathrm{NMR}\left(\mathrm{CDCl}_{3}, 128 \mathrm{MHz}\right): \delta=0.36 \mathrm{ppm}\left(\mathrm{t},{ }^{1} J_{(\mathrm{B}, \mathrm{F})}=30.5 \mathrm{~Hz}\right) ; \mathrm{MS}$ (ESI-TOF): $m / z$ : calcd for $\mathrm{C}_{21} \mathrm{H}_{23} \mathrm{BClF}_{2} \mathrm{~N}_{2} \mathrm{O}: 402.1591$; found: $402.1564[M+\mathrm{H}]^{+}$.

BODIPY 12: Yield: $17.4 \mathrm{mg}, 86.6 \%$; ${ }^{1} \mathrm{H}$ NMR $\left(400 \mathrm{MHz}, \mathrm{CDCl}_{3}\right): \delta=6.93-7.25(5 \mathrm{H}, \mathrm{m})$, $6.55(1 \mathrm{H}, \mathrm{s}), 2.55(3 \mathrm{H}, \mathrm{s}), 2.31-2.37\left(2 \mathrm{H}, \mathrm{q},{ }^{3} J_{(\mathrm{H}, \mathrm{H})}=7.4 \mathrm{~Hz}\right), 1.98(3 \mathrm{H}, \mathrm{s}), 1.91(3 \mathrm{H}, \mathrm{s})$, $1.89(3 \mathrm{H}, \mathrm{s}), 1.00-1.03 \mathrm{ppm}\left(3 \mathrm{H}, \mathrm{t},{ }^{3} J_{(\mathrm{H}, \mathrm{H})}=7.6 \mathrm{~Hz}\right) ;{ }^{13} \mathrm{C}\left(100 \mathrm{MHz}, \mathrm{CDCl}_{3}\right): \delta=153.5$, 143.5, 140.6, 135.3 134.9, 133.0, 132.6, 129.8, 127.2, 125.5, 122.8, 118.0, 17.0, 14.7, 12.9, 12.8, 12.64, $8.8 \mathrm{ppm} ;{ }^{11} \mathrm{~B}$ NMR $\left(\mathrm{CDCl}_{3}, 128 \mathrm{MHz}\right): \delta=0.47 \mathrm{ppm}\left(\mathrm{t},{ }^{1} J_{(\mathrm{B}, \mathrm{F})}=31.1 \mathrm{~Hz}\right) ; \mathrm{MS}$ (ESI-TOF): $\mathrm{m} / z$ : calcd for $\mathrm{C}_{21} \mathrm{H}_{24} \mathrm{BClF}_{2} \mathrm{~N}_{3}$ : 401.1751; found: $401.1725[M+\mathrm{H}]^{+}$. 
BODIPY 13: Yield: $24.2 \mathrm{mg}, 93 \% ;{ }^{1} \mathrm{H}$ NMR (400 MHz, $\left.\mathrm{CDCl}_{3}\right): \delta=7.05-7.22(8 \mathrm{H}, \mathrm{m})$, $2.60(3 \mathrm{H}, \mathrm{s}), 2.36-2.41(5 \mathrm{H}, \mathrm{m}$, overlapped), $2.31(6 \mathrm{H}, \mathrm{s}), 2.29(3 \mathrm{H}, \mathrm{s}), 1.72(3 \mathrm{H}, \mathrm{s})$, $1.01-1.04 \mathrm{ppm}\left(3 \mathrm{H}, \mathrm{t},{ }^{3} \mathrm{~J}_{(\mathrm{H}, \mathrm{H})}=6.0 \mathrm{~Hz}\right) ;{ }^{13} \mathrm{C} \mathrm{NMR}\left(100 \mathrm{MHz}, \mathrm{CDCl}_{3}\right): \delta=160.4,143.6$, 141.9, 138.2, 137.2, 136.3, 135.9, 134.3, 133.0, 132.8, 132.1, 131.7, 130.3, 129.8, 129.4, 126.3, 21.1, 21.0, 17.2, 14.5, 14.4, 13.2, $10.1 \mathrm{ppm} ;{ }^{11} \mathrm{~B} \mathrm{NMR}\left(\mathrm{CDCl}_{3}, 128 \mathrm{MHz}\right): \delta=0.51$ ppm (t, ${ }^{1} J_{(\mathrm{B}, \mathrm{F})}=31.5 \mathrm{~Hz}$ ); MS (ESI-TOF): $m / z$ : calcd for $\mathrm{C}_{29} \mathrm{H}_{32} \mathrm{BF}_{2} \mathrm{~N}_{2} \mathrm{~S}_{2}: 520.2099$; found: $520.2085[M+\mathrm{H}]^{+}$.

BODIPY 14: Into a $5 \mathrm{~mL}$ round-bottom flask were added BODIPY 7c $(19.3 \mathrm{mg}, 0.05$ mmol), thiolcarborane ( $88 \mathrm{mg}, 0.5 \mathrm{mmol})$, and $\mathrm{K}_{2} \mathrm{CO}_{3}(13.8 \mathrm{mg}, 0.1 \mathrm{mmol}) . \mathrm{CH}_{2} \mathrm{Cl}_{2}(1 \mathrm{~mL})$ was added into the flask. The mixture was then stirred at room temperature. The reaction was quenched with water when TLC analysis showed the disappearance of starting material. $\mathrm{CH}_{2} \mathrm{Cl}_{2}(10 \mathrm{~mL} \times 3)$ was used to extract the organic components. Organic solvents were combined, dried over anhydrous $\mathrm{Na}_{2} \mathrm{SO}_{4}$, and evaporated under reduced pressure to give the crude product. Further purification by silica gel column chromatography with ethyl acetate/ hexanes as the eluent gave the titled product $(17.7 \mathrm{mg}, 67.3 \%) .{ }^{1} \mathrm{H} \mathrm{NMR}(400 \mathrm{MHz}$, $\left.\mathrm{CDCl}_{3}\right): \delta=7.24-7.5(5 \mathrm{H}, \mathrm{m}), 4.59(1 \mathrm{H}, \mathrm{s}), 1.76-3.34(10 \mathrm{H}, \mathrm{m}), 2.63(3 \mathrm{H}, \mathrm{s}), 2.32-2.38(2$ $\left.\mathrm{H}, \mathrm{q},{ }^{3} J_{(\mathrm{H}, \mathrm{H})}=7.6 \mathrm{~Hz}\right), 2.04(3 \mathrm{H}, \mathrm{s}), 1.36(3 \mathrm{H}, \mathrm{s}), 1.29(3 \mathrm{H}, \mathrm{s}), 0.99-1.03 \mathrm{ppm}(3 \mathrm{H}$, t, $\left.{ }^{3} J_{(\mathrm{H}, \mathrm{H})}=7.5 \mathrm{~Hz}\right) ;{ }^{13} \mathrm{C} \mathrm{NMR}\left(100 \mathrm{MHz}, \mathrm{CDCl}_{3}\right): \delta=165.0,143.4,141.6,137.3,135.5$, 134.9, 134.7, 134.2, 133.3, 132.5, 129.4(t), 128.0, 127.9, 66.3, 66.2, 17.1, 14.1, 13.6, 12.2, 12.1, $11.1 \mathrm{ppm} ;{ }^{11} \mathrm{~B} \mathrm{NMR}\left(\mathrm{CDCl}_{3}, 128 \mathrm{MHz}\right): \delta=0.29\left(1 \mathrm{~B}, \mathrm{t},{ }^{1} J_{(\mathrm{B}, \mathrm{F})}=31.1 \mathrm{~Hz}\right),-0.85(1 \mathrm{~B}$, $\left.\mathrm{d},{ }^{1} J_{(\mathrm{B}, \mathrm{H})}=142 \mathrm{~Hz}\right),-4.74\left(1 \mathrm{~B}, \mathrm{~d},{ }^{1} J_{(\mathrm{B}, \mathrm{H})}=128 \mathrm{~Hz}\right),-10.1$ to $-12.92 \mathrm{ppm}(8 \mathrm{~B}, \mathrm{~m}) ; \mathrm{MS}$ (ESI-TOF): $\mathrm{m} / z$ : calcd for $\mathrm{C}_{23} \mathrm{H}_{24} \mathrm{~B}_{11} \mathrm{~F}_{2} \mathrm{~N}_{2} \mathrm{~S}$ : 527.3520; found: $527.3512[M+\mathrm{H}]^{+}$.

BODIPY 15: Into a $50 \mathrm{~mL}$ round-bottom flask was added meso-substiutued BODIPY 11 (10 $\mathrm{mg}, 0.025 \mathrm{mmol})$ and $\left[\mathrm{Pd}\left(\mathrm{PPh}_{3}\right)_{4}\right](10 \mathrm{~mol} \%)$. The flask was then evacuated and refilled with argon 3 times. Dry toluene $(20 \mathrm{~mL})$ and 2-(tributylstannyl)thiophene $(0.05 \mathrm{mmol})$ were introduced into the flask. The mixture was refluxed for $6 \mathrm{~h}$ under an argon atmosphere. The reaction was stopped when TLC analysis showed the disappearance of starting material. Toluene was removed under reduced pressure. A flash column chromatography $\left(\mathrm{CH}_{2} \mathrm{Cl}_{2}\right.$ as the eluent) was used to obtain the crude product. Further purification by silica gel column chromatography with ethyl acetate/hexanes as the eluent gave the desired product. Yield: $10.2 \mathrm{mg}, 90.6 \% ;{ }^{1} \mathrm{H} \mathrm{NMR}\left(400 \mathrm{MHz}, \mathrm{CDCl}_{3}\right): \delta=7.50-7.53(2 \mathrm{H}, \mathrm{m}), 7.32-7.36(2 \mathrm{H}, \mathrm{m})$, $7.17-7.19\left(1 \mathrm{H}, \mathrm{q},{ }^{3} J_{(\mathrm{H}, \mathrm{H})}=3.6,{ }^{3} J_{(\mathrm{H}, \mathrm{H})}=1.5 \mathrm{~Hz}\right), 7.05-7.10(3 \mathrm{H}, \mathrm{m}), 2.50(3 \mathrm{H}, \mathrm{s}), 2.31-2.37$ $\left(2 \mathrm{H}, \mathrm{q},{ }^{3} J_{(\mathrm{H}, \mathrm{H})}=7.6 \mathrm{~Hz}\right), 2.04(3 \mathrm{H}, \mathrm{s}), 2.02(3 \mathrm{H}, \mathrm{s}), 1.99(3 \mathrm{H}, \mathrm{s}), 0.99-1.03 \mathrm{ppm}(3 \mathrm{H}$, $\left.\mathrm{t},{ }^{3} J_{(\mathrm{H}, \mathrm{H})}=7.6 \mathrm{~Hz}\right) ;{ }^{13} \mathrm{C}\left(100 \mathrm{MHz}, \mathrm{CDCl}_{3}\right): \delta=157.8,157.7,150.9,145.4,137.4,135.3$, 133.6, 132.7, 130.4 (t), 130.1, 128.3, 127.6, 127.0, 126.7, 123.0, 122.8, 114.9, 17.0, 14.5, 13.0, 11.9, 11.7, $10.2 \mathrm{ppm} ;{ }^{11} \mathrm{~B} \mathrm{NMR}\left(\mathrm{CDCl}_{3}, 128 \mathrm{MHz}\right): \delta=0.64 \mathrm{ppm}\left(\mathrm{t},{ }^{1} J_{(\mathrm{B}, \mathrm{F})}=32.0 \mathrm{~Hz}\right)$; MS (ESI-TOF): $m / z$ : calcd for $\mathrm{C}_{25} \mathrm{H}_{26} \mathrm{BF}_{2} \mathrm{~N}_{2} \mathrm{OS}$ : 450.1858; found: $450.1831[M+\mathrm{H}]^{+}$.

BODIPY 16: Into a $50 \mathrm{~mL}$ round-bottom flask was added BODIPY 6c $(21.4 \mathrm{mg}, 0.05$ $\mathrm{mmol})$, molecular sieves, and methyl 4-formylanisole $(68 \mathrm{mg}, 0.5 \mathrm{mmol})$ in toluene (10 $\mathrm{mL}) . p$ - $\mathrm{TsOH}(10 \mathrm{mg})$ and piperidine $(0.1 \mathrm{~mL})$ were added into the mixture. The mixture was stirred and refluxed for $72 \mathrm{~h}$ under an argon atmosphere. The reaction was stopped when TLC analysis showed the disappearance of starting material. The mixture was cooled 
to room temperature and filtered to remove the moleculer sieves. The filtrate was poured into water $(20 \mathrm{~mL})$ and $\mathrm{CH}_{2} \mathrm{Cl}_{2}(20 \mathrm{~mL} \times 3)$ was used to extract the organic components. The organic solvents were combined, dried over anhydrous $\mathrm{Na}_{2} \mathrm{SO}_{4}$, and evaporated under reduced pressure to give the crude product. Further purification by silica gel column chromatography with ethyl acetate/hexanes as the eluent gave the styryl-BODIPY 16 (14.2 $\mathrm{mg}, 52 \%) .{ }^{1} \mathrm{H}$ NMR $\left(400 \mathrm{~Hz}, \mathrm{CDCl}_{3}\right): \delta=7.13-7.60(14 \mathrm{H}, \mathrm{m}), 6.85-6.87\left(2 \mathrm{H}, \mathrm{d},{ }^{3} J_{(\mathrm{H}, \mathrm{H})}=\right.$ $8 \mathrm{~Hz}), 3.83(3 \mathrm{H}, \mathrm{s}), 2.56-2.62\left(2 \mathrm{H}, \mathrm{q},{ }^{3} J_{(\mathrm{H}, \mathrm{H})}=7.5 \mathrm{~Hz}\right), 1.80(3 \mathrm{H}, \mathrm{s}), 1.36(6 \mathrm{H}, \mathrm{s}), 1.13-$ $1.16 \mathrm{ppm}\left(3 \mathrm{H}, \mathrm{t},{ }^{3} J_{(\mathrm{H}, \mathrm{H})}=7.3 \mathrm{~Hz}\right) ;{ }^{13} \mathrm{C} \mathrm{NMR}\left(400 \mathrm{~Hz}, \mathrm{CDCl}_{3}\right): \delta=160.3,154.1,152.1$, 140.3, 140.1, 138.4, 136.2, 136.1, 133.9, 132.9, 132.8, 131.9, 130.0, 129.1, 128.9, 128.5, 127.7, 127.2, 117.9, 114.1, 55.4, 18.4, 14.0, 12.2, 11.6, 9.8 ppm; ${ }^{11} \mathrm{~B}$ NMR $\left(\mathrm{CDCl}_{3}, 128\right.$ $\mathrm{MHz}): \delta=0.90 \mathrm{ppm}\left(\mathrm{t},{ }^{1} J_{(\mathrm{B}, \mathrm{F})}=32.7 \mathrm{~Hz}\right)$; MS (ESI-TOF): $\mathrm{m} / z$ : calcd for $\mathrm{C}_{35} \mathrm{H}_{33} \mathrm{BF}_{2} \mathrm{~N}_{2} \mathrm{O}$ : 545.2685; found: $545.2687[M+\mathrm{H}]^{+}$.

BODIPY 17: Into a $50 \mathrm{~mL}$ round-bottom flask was added BODIPY $\mathbf{6 c}(21.4 \mathrm{mg}, 0.05$ $\mathrm{mmol})$. The flask was then evacuated and refilled with argon 3 times. Dry toluene $(10 \mathrm{~mL})$ was added. The temperature was raised to $110^{\circ} \mathrm{C}$. A solution of DDQ $(56.8 \mathrm{mg}, 0.25 \mathrm{mmol})$ in toluene $(10 \mathrm{~mL})$ was added slowly into the mixture, which was stirred and refluxed under an argon atmosphere. The reaction was stopped when TLC analysis showed the disappearance of starting material. Solvents were removed under reduced pressure to give the crude product. Further purification by silica gel column chromatography or preparative TLC plates with ethyl acetate/hexanes as the eluent gave BODIPY $17(5.7 \mathrm{mg}, 25.8 \%$ yield). ${ }^{1} \mathrm{H} \mathrm{NMR}\left(400 \mathrm{~Hz}, \mathrm{CDCl}_{3}\right): \delta=10.30(1 \mathrm{H}, \mathrm{s}), 7.37-7.59(5 \mathrm{H}, \mathrm{m}), 2.67-2.71(2 \mathrm{H}$, q, $\left.{ }^{3} J_{(\mathrm{H}, \mathrm{H})}=7.4 \mathrm{~Hz}\right), 1.84(3 \mathrm{H}, \mathrm{s}), 1.44(3 \mathrm{H}, \mathrm{s}), 1.31(3 \mathrm{H}, \mathrm{s}), 1.00-1.03 \mathrm{ppm}(3 \mathrm{H}$, t, $\left.{ }^{3} J_{(\mathrm{H}, \mathrm{H})}=7.1 \mathrm{~Hz}\right) ;{ }^{13} \mathrm{C} \mathrm{NMR}\left(400 \mathrm{~Hz}, \mathrm{CDCl}_{3}\right): \delta=186.3,164.5,144.7,144.5,141.2,137.2$, $136.3,135.8,134.9,132.6,131.5,130.9,130.0,129.6,129.5,129.3,128.1,127.8,17.6$, 14.3, 12.9, 10.7, $10.0 \mathrm{ppm} ;{ }^{11} \mathrm{~B} \mathrm{NMR}\left(\mathrm{CDCl}_{3}, 128 \mathrm{MHz}\right): \delta=0.69 \mathrm{ppm}\left(\mathrm{t},{ }^{1} J_{(\mathrm{B}, \mathrm{F})}=32.1 \mathrm{~Hz}\right)$; MS (ESI-TOF): $m / z$ : calcd for $\mathrm{C}_{27} \mathrm{H}_{26} \mathrm{BF}_{2} \mathrm{~N}_{2} \mathrm{O}: 442.2137$; found: $442.2145[M+\mathrm{H}]^{+}$.

\section{Crystal data}

Diffraction data were collected at low temperature (90-105 K) on either a Nonius KappaCCD diffractometer equipped with $\mathrm{Mo}_{\mathrm{Ka}}$ radiation $(\lambda=0.71073 \AA$ ) or a Bruker Kappa Apex-II DUO diffractometer equipped with $\mathrm{Mo}$ or $\mathrm{Cu}_{\mathrm{Ka}}$ radiation $(\lambda=1.54184 \AA)$. Refinement was by full-matrix least squares using SHELXL, with $\mathrm{H}$ atoms in idealized positions, except for those on $\mathrm{N}$ in $\mathbf{3}, \mathbf{4}$, and $\mathbf{1 2}$, which were refined. BODIPYS $1 \mathrm{a}$ and $\mathbf{1 6}$ have two independent molecules, and $\mathbf{1 b}$ has four. 1a, $\mathbf{6 b}$, and $\mathbf{1 6}$ were nonmerohedral twins, and disorder was present in 1a, 6a-c, 8, 11, and 12. Compounds 1a and $\mathbf{1 7}$ were chloroform solvates. The absolute structures of both noncentrosymmetric crystals $\mathbf{1 b}$ and $\mathbf{7 c}$ were determined. For 1a: $\mathrm{C}_{15} \mathrm{H}_{17} \mathrm{BCl}_{2} \mathrm{~F}_{2} \mathrm{~N}_{2} \cdot 0.5 \mathrm{CHCl}_{3}$, triclinic $P-1, a=8.4888(3)$, $b=13.9111(6), c=14.8676(6) \AA, \alpha=86.609(3), \beta=88.646(2), \gamma=89.580(2)^{\circ}, Z=4, T=90 \mathrm{~K}$, $R=0.067$; 1b: $\mathrm{C}_{15} \mathrm{H}_{18} \mathrm{BClF}_{2} \mathrm{~N}_{2}$, monoclinic $P 2_{1}, a=15.4384(5), b=11.5896(4), c=16.8479(5)$ $\AA$, $\beta=99.215(2)^{\circ}, Z=8, T=90 \mathrm{~K}, R=0.047 ; 3: \mathrm{C}_{23} \mathrm{H}_{26} \mathrm{~N}_{2} \mathrm{O}_{3}$, monoclinic $P 2{ }_{1} / n, a=7.7071(6)$, $b=12.3770(9), c=21.4131(17) \AA, \beta=92.673(4)^{\circ}, Z=4, T=100 \mathrm{~K}, R=0.045 ; 4$ : $\left[\mathrm{C}_{23} \mathrm{H}_{26} \mathrm{ClN}_{2} \mathrm{O}_{2}\right] \mathrm{Cl}$, triclinic $P-1, a=8.1637(4), b=9.5889(5), c=13.6082(8) \AA$. $\beta=97.737(2), \gamma=92.855(2)^{\circ}, Z=2, T=100 \mathrm{~K}, R=0.033$; 6a: $\mathrm{C}_{23} \mathrm{H}_{23} \mathrm{BF}_{2} \mathrm{~N}_{2} \mathrm{~S}_{2}$, triclinic $\mathrm{P}-1$, $a=9.5771(14), b=10.3269(15), c=11.567(2) \AA, \alpha=77.851(8), \beta=66.885(6), \gamma=79.384(7)^{\circ}$, 
$Z=2, T=100 \mathrm{~K}, R=0.041 ;$ 6b: $\mathrm{C}_{23} \mathrm{H}_{23} \mathrm{BF}_{2} \mathrm{~N}_{2} \mathrm{O}_{2}$, triclinic $P-1, a=9.362(2), b=10.155(2)$, $c=11.682(3) \AA, \alpha=76.840(6), \beta=66.796(6), \gamma=77.094(6)^{\circ}, Z=2, T=90 \mathrm{~K}, R=0.089 ; \mathbf{6 c}$ : $\mathrm{C}_{27} \mathrm{H}_{27} \mathrm{BF}_{2} \mathrm{~N}_{2}$, monoclinic $P 2{ }_{1} / n, a=11.4039(6), b=7.9247(4), c=24.2010(12) \AA$, $\beta=91.650(3)^{\circ}, Z=4, T=90 \mathrm{~K}, R=0.047 ; 7 \mathbf{c}: \mathrm{C}_{21} \mathrm{H}_{22} \mathrm{BClF}_{2} \mathrm{~N}_{2}$, monoclinic $P c, a=7.6918$ (2), $b=8.2818(2), c=14.8858(4) \AA, \beta=94.762(2)^{\circ}, Z=2, T=105 \mathrm{~K}, R=0.035 ; 8: \mathrm{C}_{23} \mathrm{H}_{23} \mathrm{BF}_{2} \mathrm{~N}_{2} \mathrm{OS}$, triclinic $P-1, a=9.5378(3), b=10.1969$ (3), $c=11.5554(4) \AA, \alpha=76.414(2), \beta=66.800$ (2), $\gamma=78.800(2)^{\circ}, Z=2, T=90 \mathrm{~K}, R=0.040 ; 9: \mathrm{C}_{23} \mathrm{H}_{23} \mathrm{BF}_{2} \mathrm{~N}_{2} \mathrm{OS}$, triclinic $P-1, a=9.4222(2)$, $b=10.2488(2), c=11.6233(3) \AA, \alpha=78.492(2), \beta=66.845(2), \gamma=77.813(2)^{\circ}, Z=2, T=90 \mathrm{~K}$, $R=0.043 ; 10: \mathrm{C}_{24} \mathrm{H}_{29} \mathrm{BF}_{2} \mathrm{~N}_{2} \mathrm{OSi}$, monoclinic $P 2{ }_{1} / c, a=6.9871(2), b=22.5959(8)$, $c=14.6041(6) \AA, \beta=93.098(2)^{\circ}, Z=4, T=90 \mathrm{~K}, R=0.041 ; 11: \mathrm{C}_{21} \mathrm{H}_{22} \mathrm{BClF}_{2} \mathrm{~N}_{2} \mathrm{O}$, triclinic $P-1$, $a=9.4115(3), b=10.4033(4), c=11.3995(4) \AA, \alpha=66.223(2), \beta=77.459(2), \gamma=68.527(2)^{\circ}, Z=2$, $T=90 \mathrm{~K}, R=0.051 ; 12: \mathrm{C}_{21} \mathrm{H}_{23} \mathrm{BClF}_{2} \mathrm{~N}_{3}$, monoclinic $C 2 / c, a=21.8367(10), b=8.9694(4)$, $c=21.9939(8) \AA, \beta=114.299(2)^{\circ}, Z=8, T=90 \mathrm{~K}, R=0.050 ; 14: \mathrm{C}_{23} \mathrm{H}_{33} \mathrm{~B}_{11} \mathrm{~F}_{2} \mathrm{~N}_{2} \mathrm{~S}$, triclinic $P-1$, $a=6.9030(7), b=12.0111(12), c=17.1906(14) \AA, \alpha=77.599(7), \beta=79.990(7), \gamma=83.195(7)^{\circ}$, $Z=2, T=90 \mathrm{~K}, R=0.070 ; 16: \mathrm{C}_{35} \mathrm{H}_{33} \mathrm{BF}_{2} \mathrm{~N}_{2} \mathrm{O}$, triclinic $P-1, a=11.5598(5), b=13.2476(6)$, $c=19.1537(8) \AA, \alpha=85.869(2), \beta=86.135(2), \gamma=72.967(2)^{\circ}, Z=4, T=90 \mathrm{~K}, R=0.048$; 17: $\mathrm{C}_{27} \mathrm{H}_{25} \mathrm{BF}_{2} \mathrm{~N}_{2} \mathrm{O} \cdot \mathrm{CHCl}_{3}$, triclinic $P-1, a=9.6902(5), b=10.7446(6), c=13.9386(8) \AA$, $\alpha=68.727(3), \beta=75.951(3), \gamma=73.728(3)^{\circ}, Z=2, T=90 \mathrm{~K}, R=0.037$;

CCDC 1038325, 1038326, 1038327, 1038328, 1038329, 1038330, 1038331, 1038332, $1038333,1038334,1038335,1038336,1038337,1038338,1038339$, and 1038340 contain the supplementary crystallographic data for this paper. These data can be obtained free of charge from The Cambridge Crystallographic Data Centre via www.ccdc.cam.ac.uk/ data_request/cif.

\section{Supplementary Material}

Refer to Web version on PubMed Central for supplementary material.

\section{Acknowledgments}

This work was supported by the National Science Foundation, grant CHE-1362641, and the National Institutes of Heath, grant CA132861.

\section{References}

1. Treibs A, Kreuzer FH. Justus Liebigs Ann Chem. 1968; 718:208-223.

2. a) Loudet A, Burgess K. Chem Rev. 2007; 107:4891-4932. [PubMed: 17924696] b) Ulrich G, Ziessel R, Harriman A. Angew Chem Int Ed. 2008; 47:1184-1201.Angew Chem. 2008; 120:12021219.c) Lu H, Mack J, Yang Y, Shen Z. Chem Soc Rev. 2014; 43:4778-4823. [PubMed: 24733589]

3. a) Kobayashi H, Ogawa M, Alford R, Choyke PL, Urano Y. Chem Rev. 2010; 110:2620-2640. [PubMed: 20000749] b) Crivellato E, Candussio L, Rosati AM, Bartoli-Klugmann F, Mallardi F, Decorti G. J Histochem Cytochem. 2002; 50:731-734. [PubMed: 11967284] c) Lee JJ, Lee SC, Zhai D, Ahn YH, Yeo HY, Tan YL, Chang YT. Chem Commun. 2011; 47:4508-4510.

4. a) Kurata S, Kanagawa T, Yamada K, Torimura M, Yokomaku T, Kamagata Y, Kurane R. Nucleic Acids Res. 2001; 29:34e.b) Jang HG, Park M, Wishnok JS, Tannenbaum SR, Wogan GN. Anal Biochem. 2006; 359:151-160. [PubMed: 17081492] 
5. a) Carten JD, Bradford MK, Farber SA. Developmental Biology. 2011; 360:276-285. [PubMed: 21968100] b) Peters C, Billich A, Ghobrial M, Högenauer K, Ullrich T, Nussbaumer P. J Org Chem. 2007; 72:1842-1845. [PubMed: 17249735]

6. a) Ziessel R, Ulrich G, Haefele A, Harriman A. J Am Chem Soc. 2013; 135:11330-11344. [PubMed: 23863135] b) Yilmaz MD, Bozdemir OA, Akkaya EU. Org Lett. 2006; 8:2871-2873. [PubMed: 16774278]

7. a) Coskun A, Deniz E, Akkaya EU. Org Lett. 2005; 7:5187-5189. [PubMed: 16268534] b) Golovkova TA, Kozlov DV, Neckers DC. J Org Chem. 2005; 70:5545-5549. [PubMed: 15989336]

8. a) Liu S, Lin T, Li D, Leamer L, Shan H, Li Z, Gabbaï FP, Conti PS. Theranostics. 2013; 3:181189. [PubMed: 23471211] b) Bernhard C, Goze C, Rousselin Y, Denat F. Chem Commun. 2010; 46:8267-8269.c) Tasan S, Zava O, Bertrand B, Bernhard C, Goze C, Picquet M, Le Gendre P, Harvey P, Denat F, Casini A, Bodio E. Dalton Trans. 2013; 42:6102-6109. [PubMed: 23232925]

9. a) Wagner RW, Lindsey JS. Pure Appl Chem. 1996; 68:1373-1380.b) Lee CH, Lindsey JS. Tetrahedron. 1994; 50:11427-11440.

10. Burghart A, Kim H, Welch MB, Thoresen LH, Reibenspies J, Burgess K. J Org Chem. 1999; 64:7813-7819.

11. a) Li Z, Mintzer E, Bittman R. J Org Chem. 2006; 71:1718-1721. [PubMed: 16468832] b) Wang D, Fan J, Gao X, Wang B, Sun S, Peng X. J Org Chem. 2009; 74:7675-7683. [PubMed: 19772337]

12. Wu L, Burgess K. Chem Commun. 2008:4933-4935.

13. a) White J, McGillivray G. J Org Chem. 1977; 42:4248-4251.b) Nicolaou KC, Claremon DA, Papahatjis DP. Tetrahedron Lett. 1981; 22:4647-4650.c) Wallace DM, Leung SH, Senge MO, Smith KM. J Org Chem. 1993; 58:7245-7257.

14. Tahtaoui C, Thomas C, Rohmer F, Klotz P, Duportail G, Mély Y, Bonnet D, Hibert M. J Org Chem. 2007; 72:269-272. [PubMed: 17194109]

15. a) Goud TV, Tutar A, Biellmann JF. Tetrahedron. 2006; 62:5084-5091.b) Gómez-Durán CFA, Garcia-Moreno I, Costela A, Martin V, Sastre R, Banuelos J, Arbeloa FL, Arbeloa IL, PenaCabrera E. Chem Commun. 2010; 46:5103-5105.c) Bañuelos J, Martín V, Gómez-Durán CFA, Córdoba IJA, Peña-Cabrera E, García-Moreno I, Costela Á, Pérez-Ojeda ME, Arbeloa T, Arbeloa L. Chem Eur J. 2011; 17:7261-7270. [PubMed: 21547964]

16. a) Wang H, Vicente MGH, Fronczek FR, Smith KM. Chem Eur J. 2014; 20:5064-5074. [PubMed: 24616111] b) Leen V, Yuan P, Wang L, Boens N, Dehaen W. Org Lett. 2012; 14:6150-6153. [PubMed: 23214969] c) Misra R, Dhokale B, Jadhav T, Mobin SM. Dalton Trans. 2013; 42:13658-13666. [PubMed: 23903804]

17. a) Rurack K, Kollmannsberger M, Daub J. Angew Chem Int Ed. 2001; 40:385-387.Angew Chem. 2001; 113:396-399.b) Dost Z, Atilgan S, Akkaya EU. Tetrahedron. 2006; 62:8484-8488.c) He H, Lo PC, Yeung SL, Fong WP, Ng DKP. J Med Chem. 2011; 54:3097-3102. [PubMed: 21417218] d) Uppal T, Bhupathiraju NVSDK, Vicente MGH. Tetrahedron. 2013; 69:4687-4693.e) Gibbs JH, Zhou Z, Kessel D, Fronczek FR, Pakhomova S, Vicente MGH. J Photochem Photobiol B: Biol. In press.

18. a) Baruah M, Qin W, Vallée RAL, Beljonne D, Rohand T, Dehaen W, Boens N. Org Lett. 2005; 7:4377-4380. [PubMed: 16178537] b) Rohand T, Baruah M, Qin W, Boens N, Dehaen W. Chem Commun. 2006:266-268.c) Rohand T, Qin W, Boens N, Dehaen W. Eur J Org Chem. 2006:46584663.d) Qin W, Rohand T, Dehaen W, Clifford JN, Driesen K, Beljonne D, Van Averbeke B, Van der Auweraer M, Boens N. J Phys Chem A. 2007; 111:8588-8597. [PubMed: 17696329]

19. a) Peña-Cabrera E, Aguilar-Aguilar A, González-Domínguez M, Lager E, Zamudio-Vázquez R, Godoy-Vargas J, Villanueva-García F. Org Lett. 2007; 9:3985-3988. [PubMed: 17764191] b) Arroyo IJ, Hu R, Merino G, Tang BZ, Peña-Cabrera E. J Org Chem. 2009; 74:5719-5722. [PubMed: 19572588] c) Arroyo IJ, Hu R, Tang BZ, López FI, Peña-Cabrera E. Tetrahedron. 2011; 67:7244-7250.

20. Wang H, Fronczek FR, Vicente MGH, Smith KM. J Org Chem. 2014; 79:10342-10352. [PubMed: 25268574]

21. Johnson AW, Markham E, Price R, Shaw KB. J Chem Soc. 1958:4254-4257. 
22. a) Smith KM, Craig GW, Eivazi F, Martynenko Z. Synthesis. 1980:493-495.b) Jackson AH, Supphayen D. J Chem Soc Perkin Trans 1. 1987:277-286.

23. Ballantine JA, Jackson AH, Kenner GW, McGillivray G. Tetrahedron. 1966; 22:241-259.

24. Jiao L, Yu C, Uppal T, Liu M, Li Y, Zhou Y, Hao E, Hu X, Vicente MGH. Org Biomol Chem. 2010; 8:2517-2519. [PubMed: 20390194]

25. de Rezende LCD, Emery FS. Orbital Elec J Chem. 2013; 5:62-83.

26. a) Haefele A, Zedde C, Retailleau P, Ulrich G, Ziessel R. Org Lett. 2010; 12:1672-1675. [PubMed: 20235590] b) Uppal, T. Ph D Dissertation. Louisiana State University; 2012.

27. Madhu S, Rao MR, Shaikh MS, Ravikanth M. Inorg Chem. 2011; 50:4392-4400. [PubMed: 21510624]

28. a) Lakshmi V, Ravikanth M. J Org Chem. 2013; 78:4993-5000. [PubMed: 23627718] b) Jiao L, Yu C, Li J, Wang Z, Wu M, Hao E. J Org Chem. 2009; 74:7525-7528. [PubMed: 19722510] c) Madhu S, Ravikanth M. Inorg Chem. 2012; 51:4285-4292. [PubMed: 22432414]

29. Boens N, Wang L, Leen V, Yuan P, Verbelen B, Dehaen W, Van der Auweraer M, De Borggraeve WD, Van Meervelt L, Jacobs J, Beljonne D, Tonnele C, Lazzaroni R, Rueds-Rama MJ, Orte A, Crovetto L, Talavera EM, Alvarez-Pez JM. J Phys Chem A. 2014; 118:1576-1594. [PubMed: 24552403]

30. Jiao L, Pang W, Zhou J, Wei Y, Mu X, Bai G, Hao E. J Org Chem. 2011; 76:9988-9996. [PubMed: 22077955]

31. a) Kee HL, Kirmaier C, Yu L, Thamyongkit P, Youngblood WJ, Calder ME, Ramos L, Noll BC, Bocian DF, Scheidt WR, Birge RR, Lindsey JS, Holten D. J Phys Chem B. 2005; 109:2043320443. [PubMed: 16853644] b) Brizet B, Desbois N, Bonnot A, Langlois A, Dubois A, Barbe JM, Gros CP, Goze C, Denat F, Harvey PD. Inorg Chem. 2014; 53:3392-3403. [PubMed: 24661249] c) Xu HJ, Bonnot A, Karsenti PL, Langlois A, Abdelhameed M, Barbe JM, Gros CP, Harvey PD. Dalton Trans. 2014; 43:8219-8229. [PubMed: 24671343]

32. a) Chen Y, Zhao J, Guo H, Xie L. J Org Chem. 2012; 77:2192-2206. [PubMed: 22316087] b) Chen Y, Zhao J, Xie L, Guo H, Li Q. RSC Adv. 2012; 2:3942-3953.

33. Didier P, Ulrich G, Mely Y, Ziessel R. Org Biomol Chem. 2009; 7:3639-3642. [PubMed: 19707663] 
<smiles>[R]c1cc(C)n2c1C1=C([Al])c3c([R])cc(C)n3N(C)B1B2F</smiles>

a

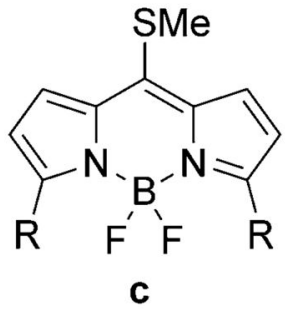<smiles></smiles>

$\mathrm{Ar}=$ aryl group $\mathrm{R}=\mathrm{H}$ or alkyl group<smiles></smiles>

Figure 1.

Examples of reported BODIPY platforms. 

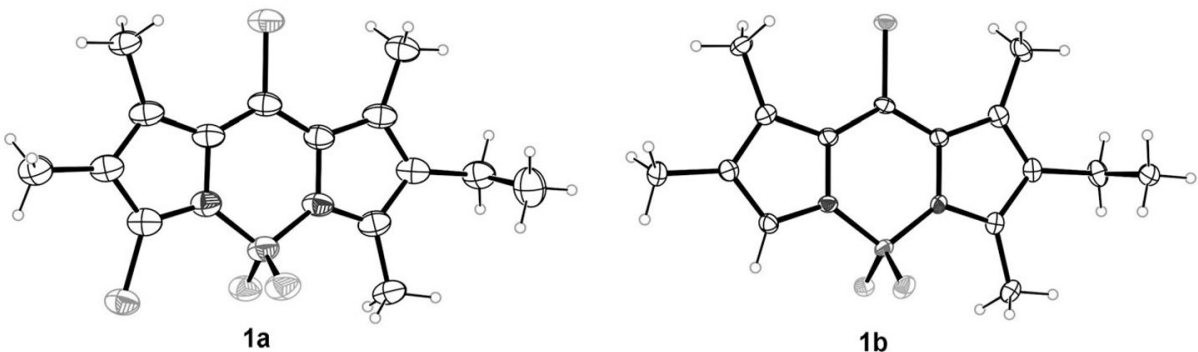

1b
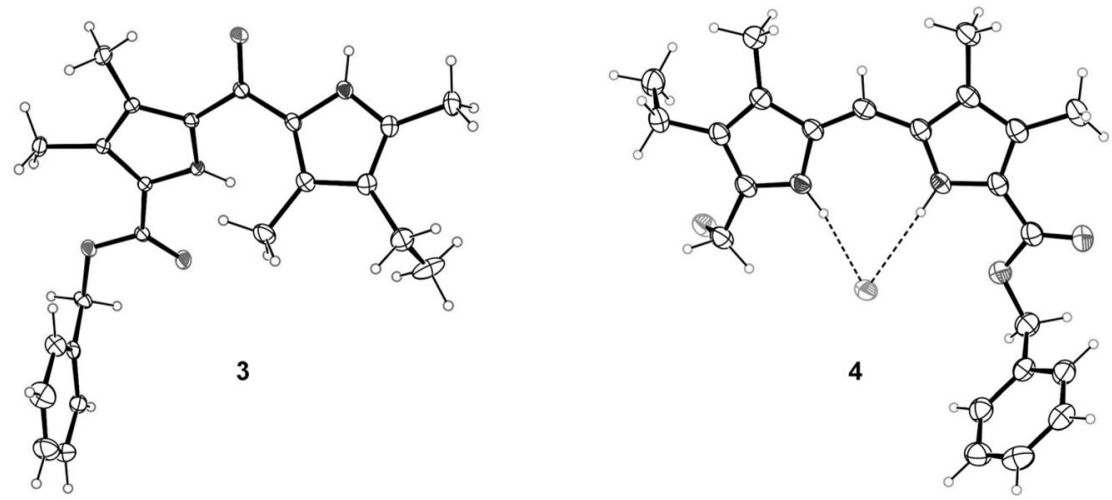

Figure 2.

X-ray crystal structures of BODIPYs 1a,b dipyrroketone $\mathbf{3}$ and dipyrryl salt $\mathbf{4}$ with $50 \%$ probability ellipsoids. Only one of the independent molecules is shown for both $\mathbf{1 a}$ and $\mathbf{1 b}$. 

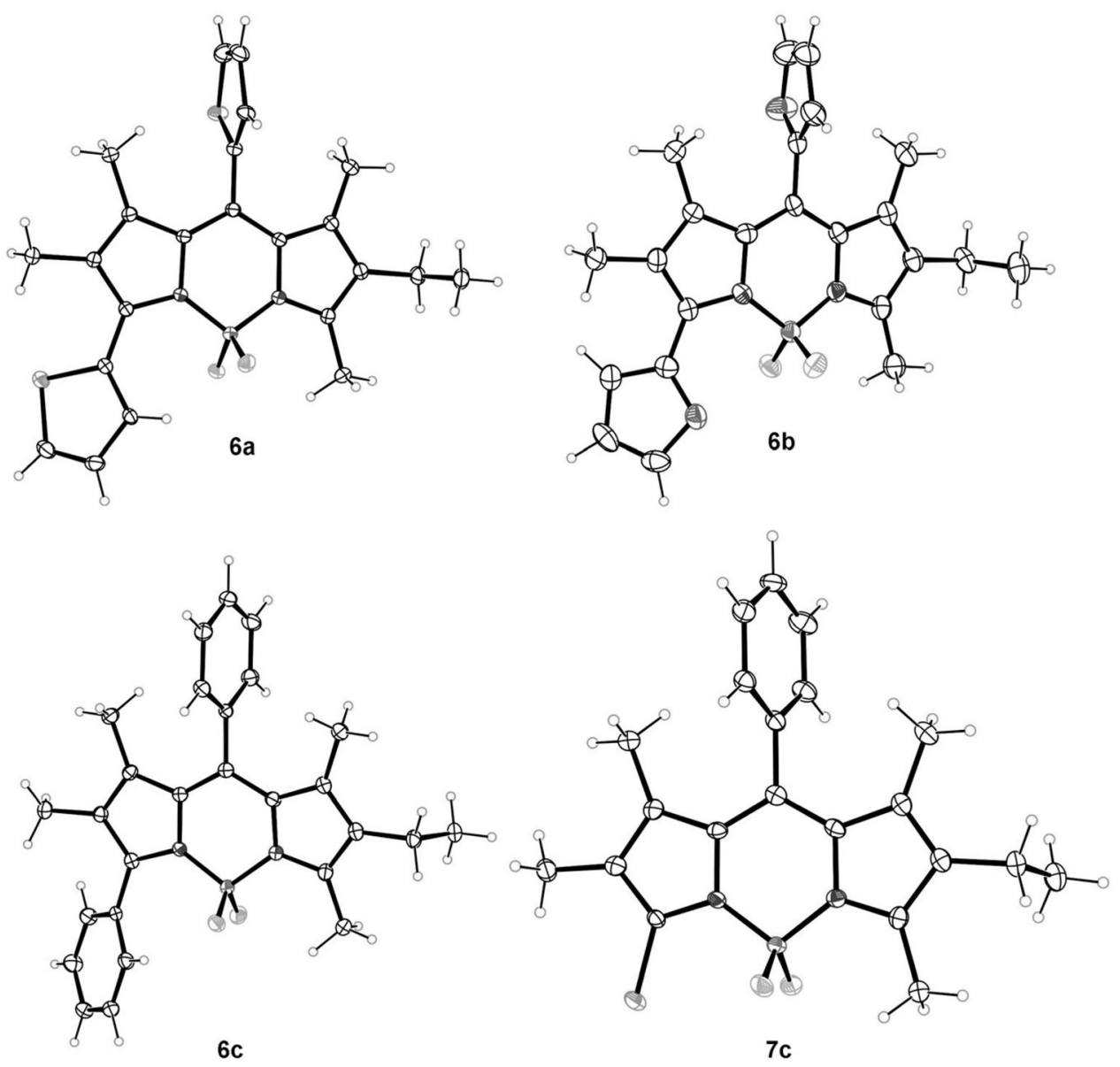

Figure 3.

X-ray crystal structures of asymmetric BODIPY dyes 6a-c and 7c (50\% probability ellipsoids). Only the major conformer is shown for disordered groups. 

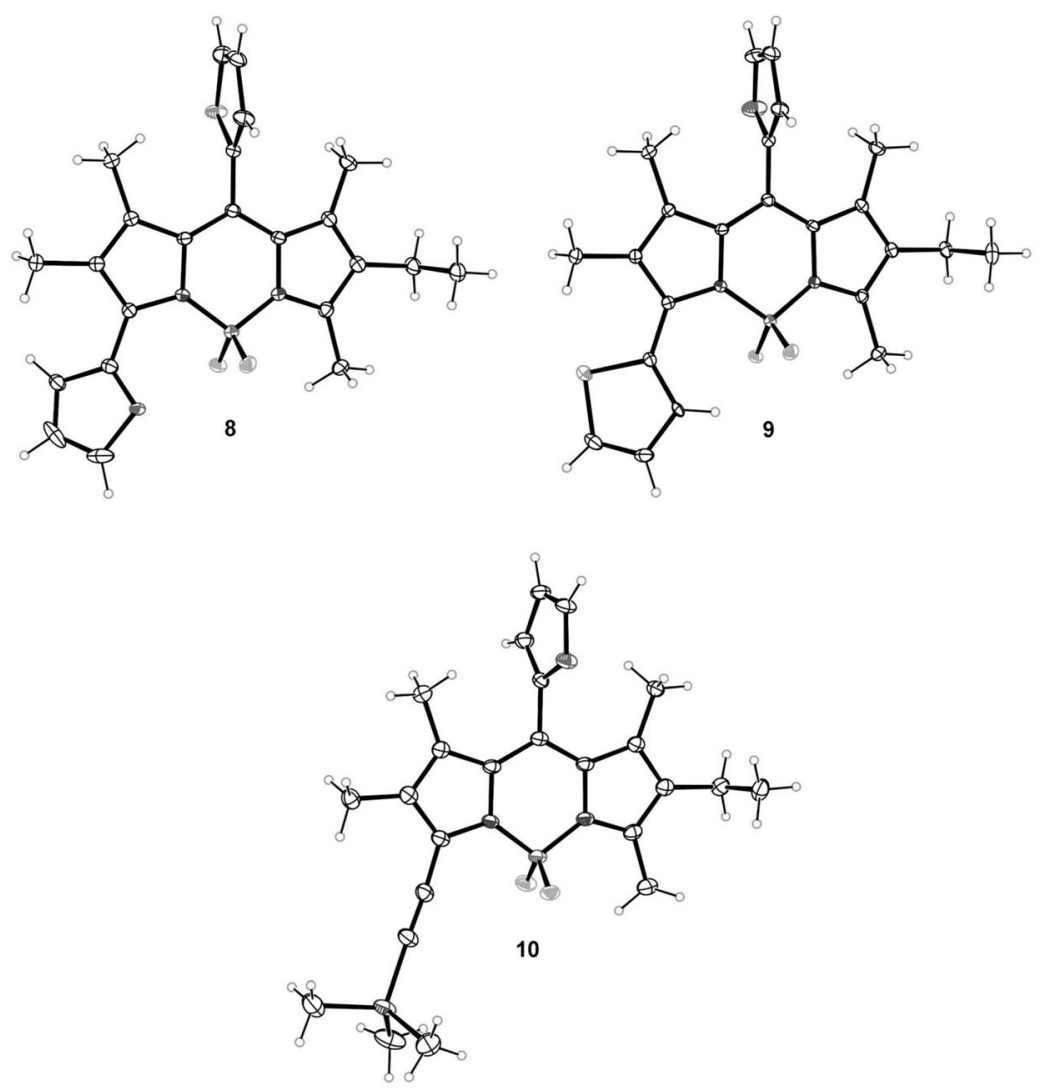

Figure 4.

X-ray crystal structures of asymmetric BODIPY dyes 8-10 (50\% probability ellipsoids). Only the main conformers are shown for the disordered thiophene and furan in $\mathbf{8}$. 


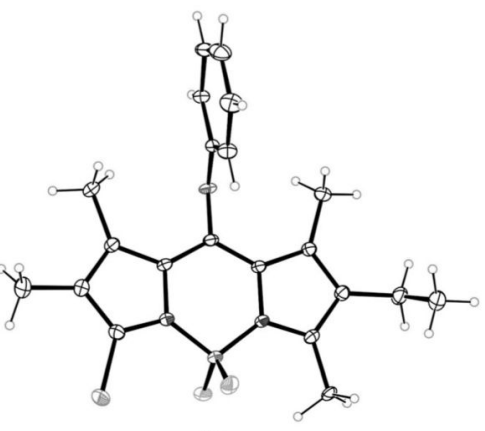

11

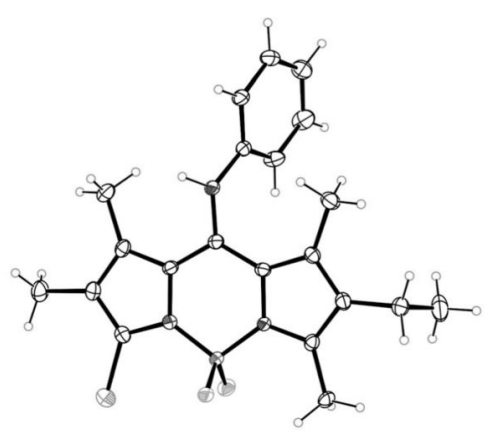

12

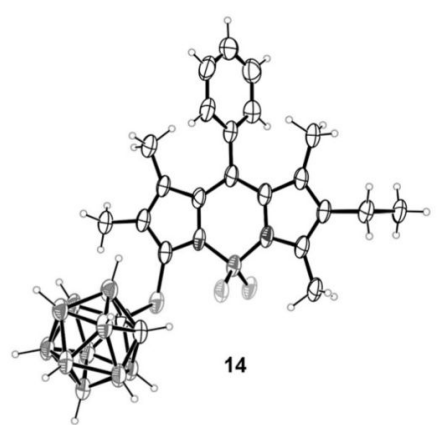

Figure 5.

X-ray crystal structures of asymmetric BODIPYS 11, 12, and 14 (50\% probability ellipsoids). The disorder in $\mathbf{1 1}$ and $\mathbf{1 2}$ is not shown. 

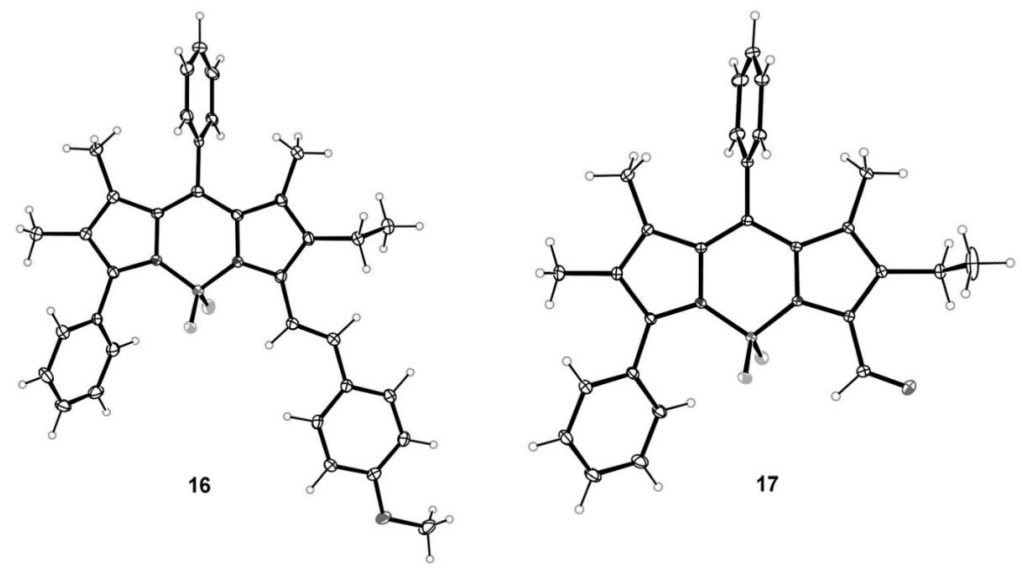

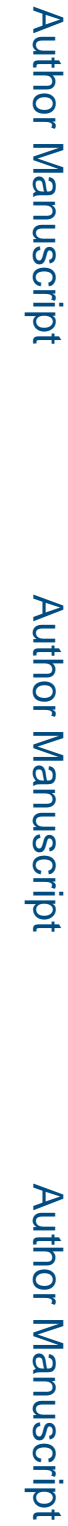

Figure 6.

X-ray crystal structures of asymmetric BODIPYS 16 and 17 (50\% probability ellipsoids). Only one of the two independent molecules of $\mathbf{1 6}$ is shown. 


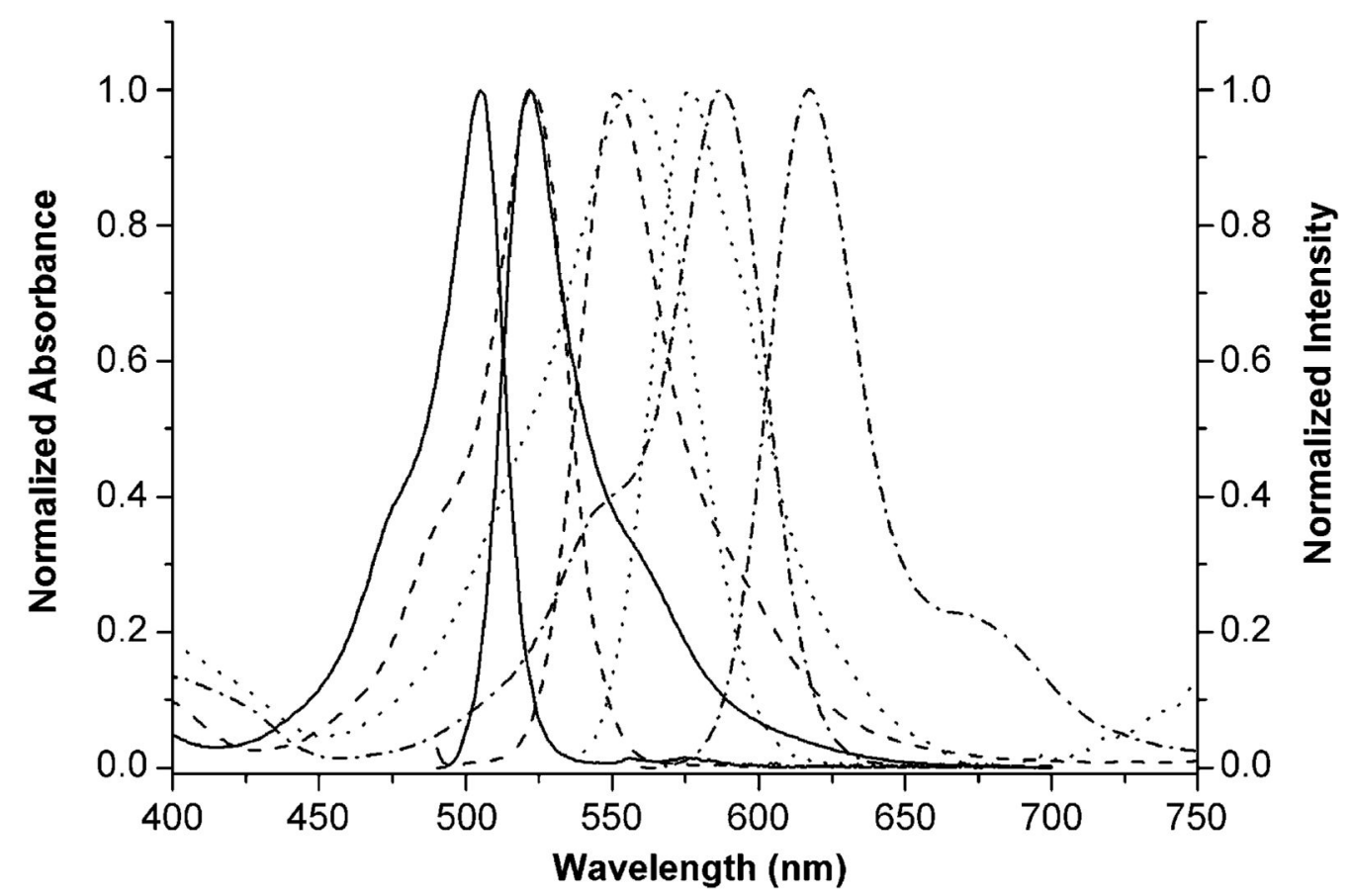

Figure 7.

Normalized UV/Vis and fluorescence spectra of BODIPYs 6c (dash), 9 (dot), 11 (solid) and 16 (dash dot) in dichloromethane at room temperature. 
<smiles>[R]c1[nH]c(C(=O)OCc2ccccc2)c(C)c1C</smiles>

2a,b,c
a: $R_{a x,}=\mathrm{Me}$
b: $\mathrm{R}=\mathrm{CO}_{2} \mathrm{H}$
c: $\mathrm{R}=\mathrm{CONMe}_{2}$<smiles>CCc1c(C)[nH]c(C(=O)c2[nH]c(C(=O)OCc3ccccc3)c(C)c2C)c1C</smiles>

3<smiles>CC(C)CC(=O)C(C)C</smiles><smiles>CCc1c(C=O)[nH]c(C=Cc2[nH]c(C(=O)OCc3ccccc3)c(C)c2C)c1CCl</smiles>

1. $\mathrm{Pd} / \mathrm{C}, \mathrm{H}_{2}, \mathrm{THF}$

2. $\mathrm{I}_{2}, \mathrm{NaHCO}_{3}, \mathrm{MeOH} / \mathrm{H}_{2}$ ( $84 \%$ for 2 steps)<smiles>CCc1c(C)[nH]c(C(=O)c2[nH]c(I)c(C)c2C)c1C</smiles>

1. $\mathrm{COCl}_{2}, \mathrm{CHCl}_{3}, \mathrm{RT}$ 2. $\mathrm{DIEA}, \mathrm{BF}_{3} \cdot \mathrm{OEt}_{2}$ (78\% for 2 steps)<smiles>[R]c1c(C)c(C)c2n1B(F)P(F)n1c(C)c(CC)c(C)c1-2</smiles>

1a: $\mathrm{R}=\mathrm{Cl}$

1b: $R=H$

Scheme 1.

Synthesis of asymmetric 3,8-dichloro-BODIPY $\mathbf{1 a .}$ 
<smiles>CCc1c(C)c2n(c1C)B(F)n1c(Cl)c(C)c(C)c1C2Cl</smiles>

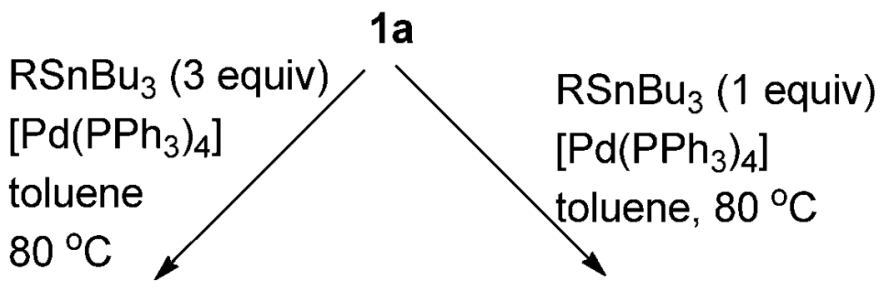<smiles></smiles><smiles></smiles><smiles>[R10]Cc1cccs1</smiles><smiles>[Te]C#[Z]c1cccs1</smiles><smiles>[R9]#Cc1ccco1</smiles>
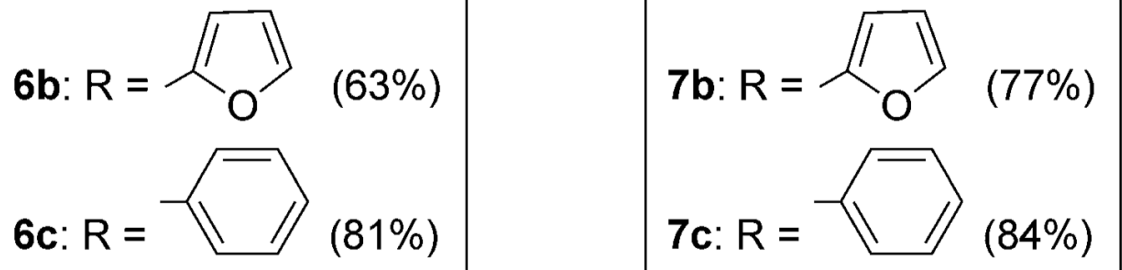

Scheme 2.

Global and regioselective Stille coupling reactions of 3,8-dichloro-BODIPY 1 a. 
<smiles>CCc1c(C)c2n(c1C)B(F)n1c(Cl)c(C)c(C)c1C2Cl</smiles>

1a

1. $R^{1}-\mathrm{SnBu}_{3}$ (1 equiv) $\left[\mathrm{Pd}\left(\mathrm{PPh}_{3}\right)_{4}\right]$

2. $\mathrm{R}^{2}-\mathrm{SnBu}_{3}$ (1 equiv)

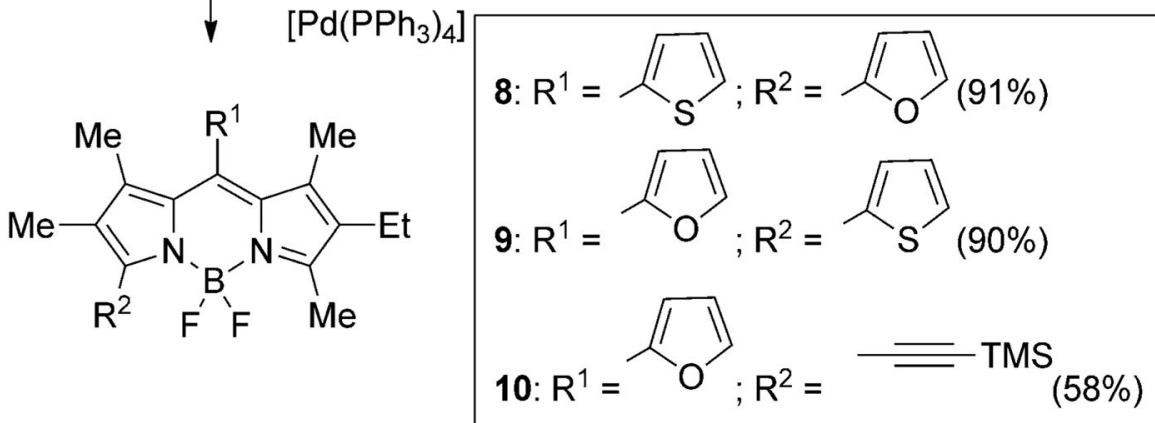

Scheme 3.

Sucessive Stille coupling reactions of 3,8-dichloro-BODIPY 1a. 


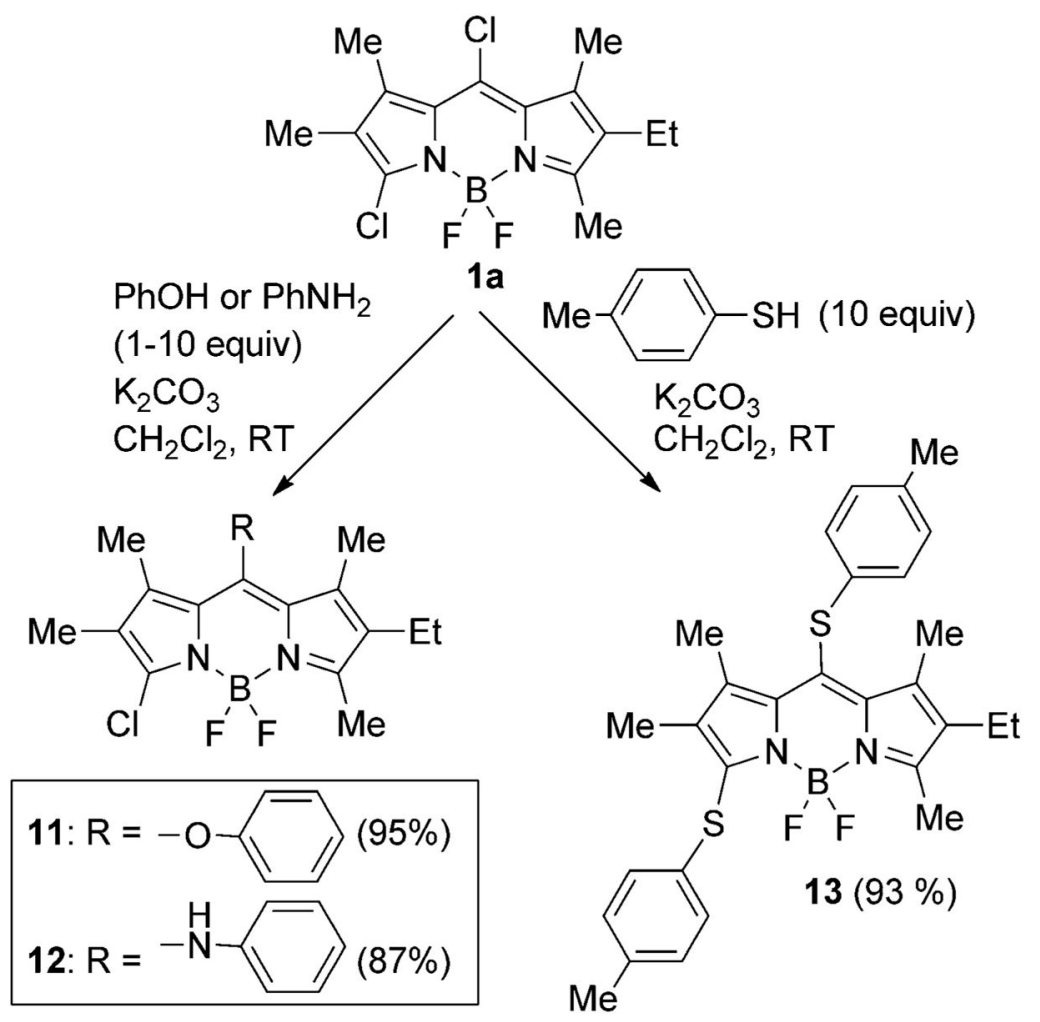

Scheme 4.

Nucleophilic additions/eliminations of BODIPY $1 \mathbf{a}$. 


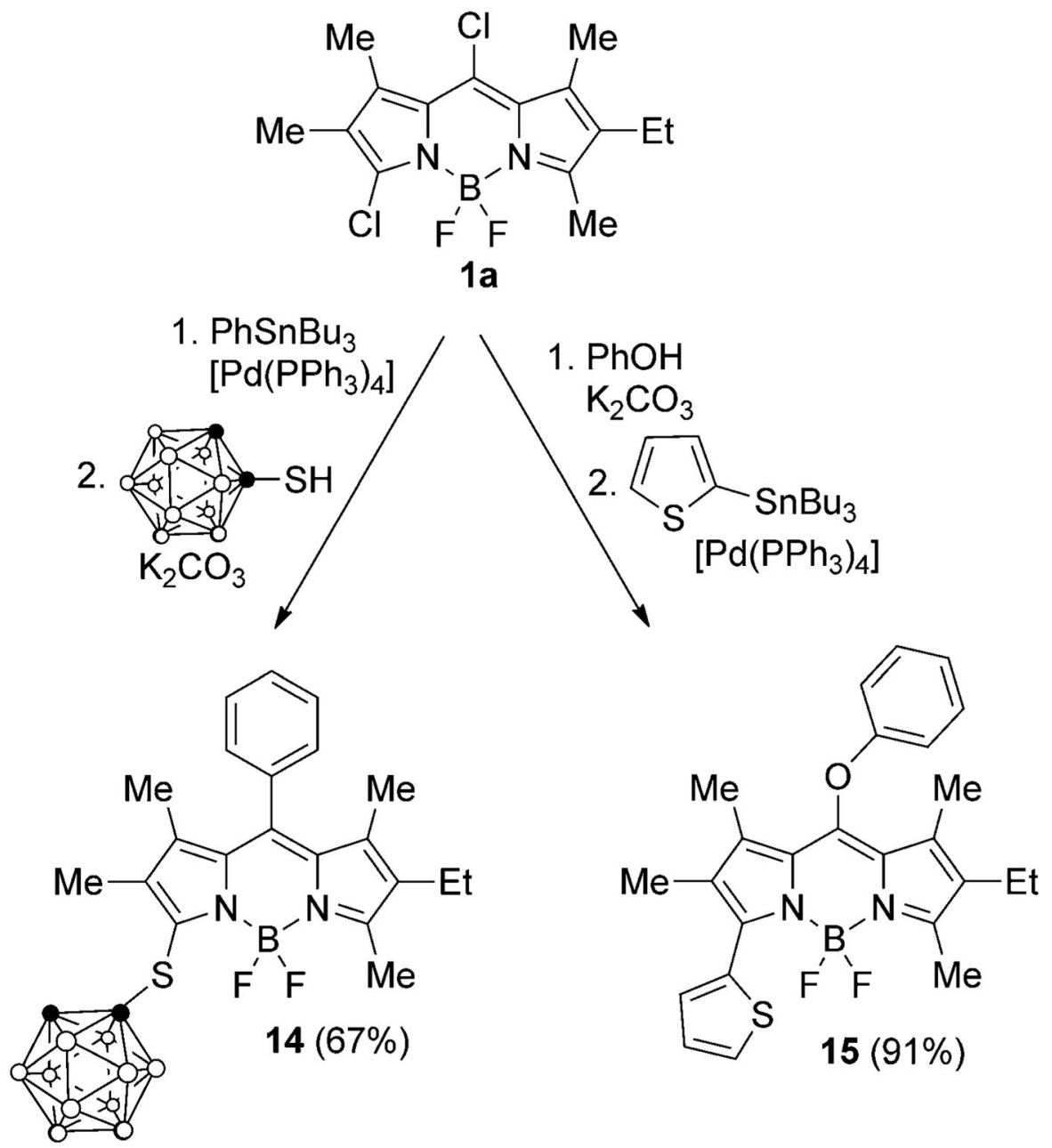

$1 a$
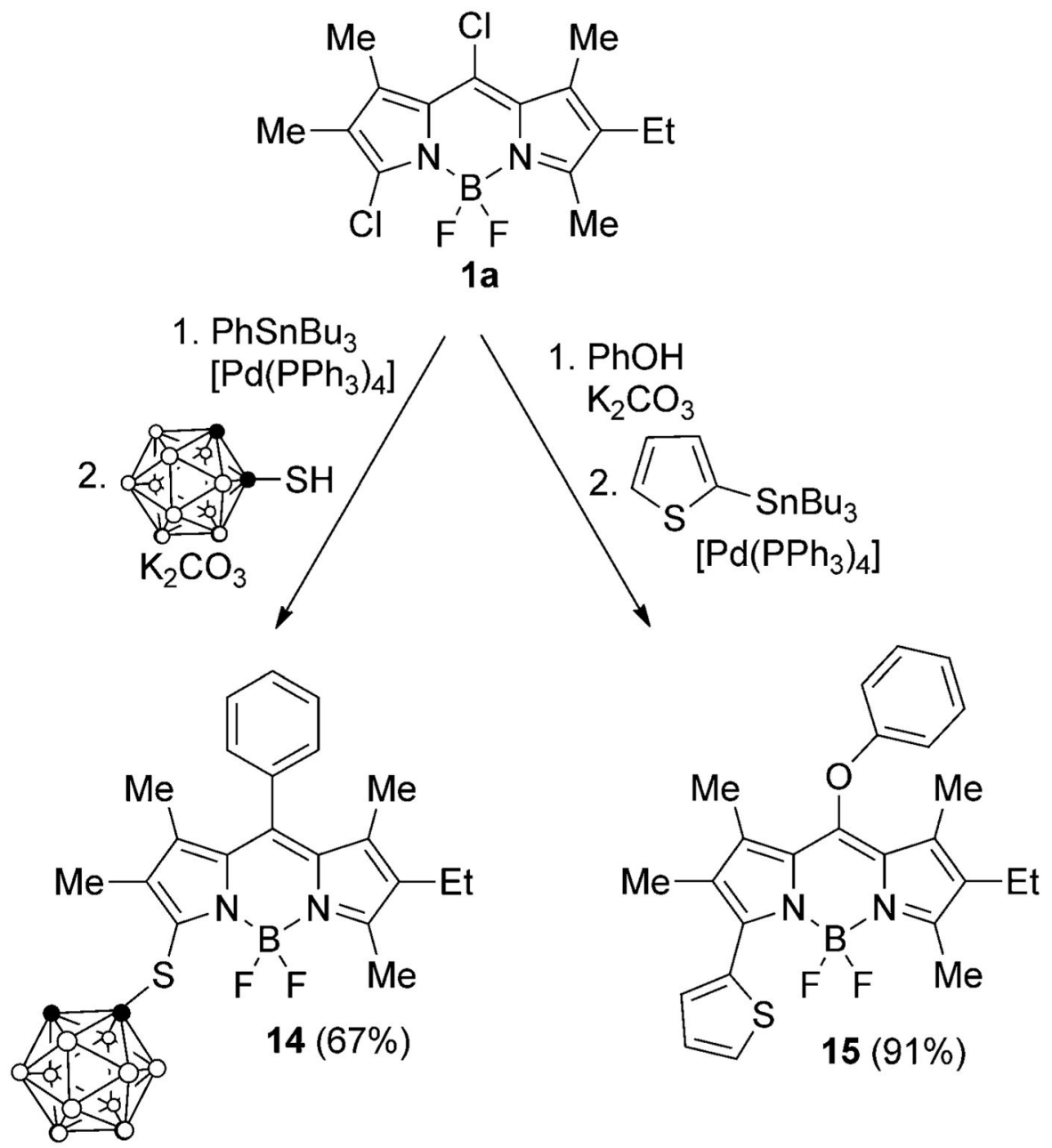

Scheme 5.

Sucessive Stille cross-coupling and nucleophilic reactions of BODIPY 1 a. 
<smiles></smiles>
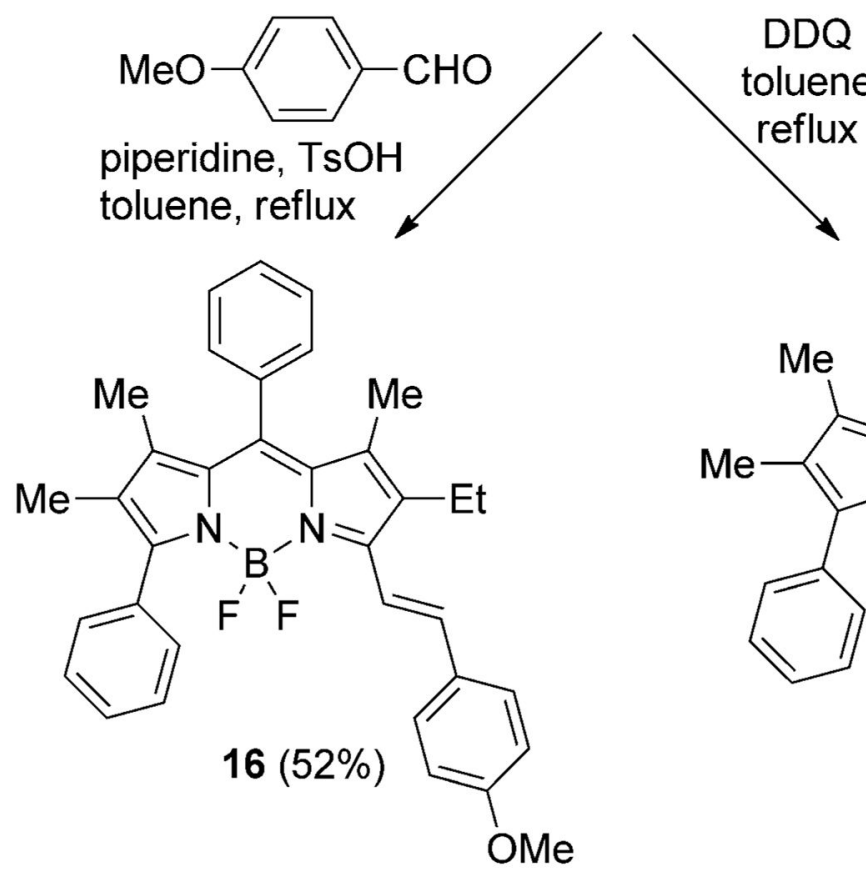<smiles></smiles>

Scheme 6.

Knoevenagel and oxidation reactions of BODIPY $\mathbf{6 c}$. 


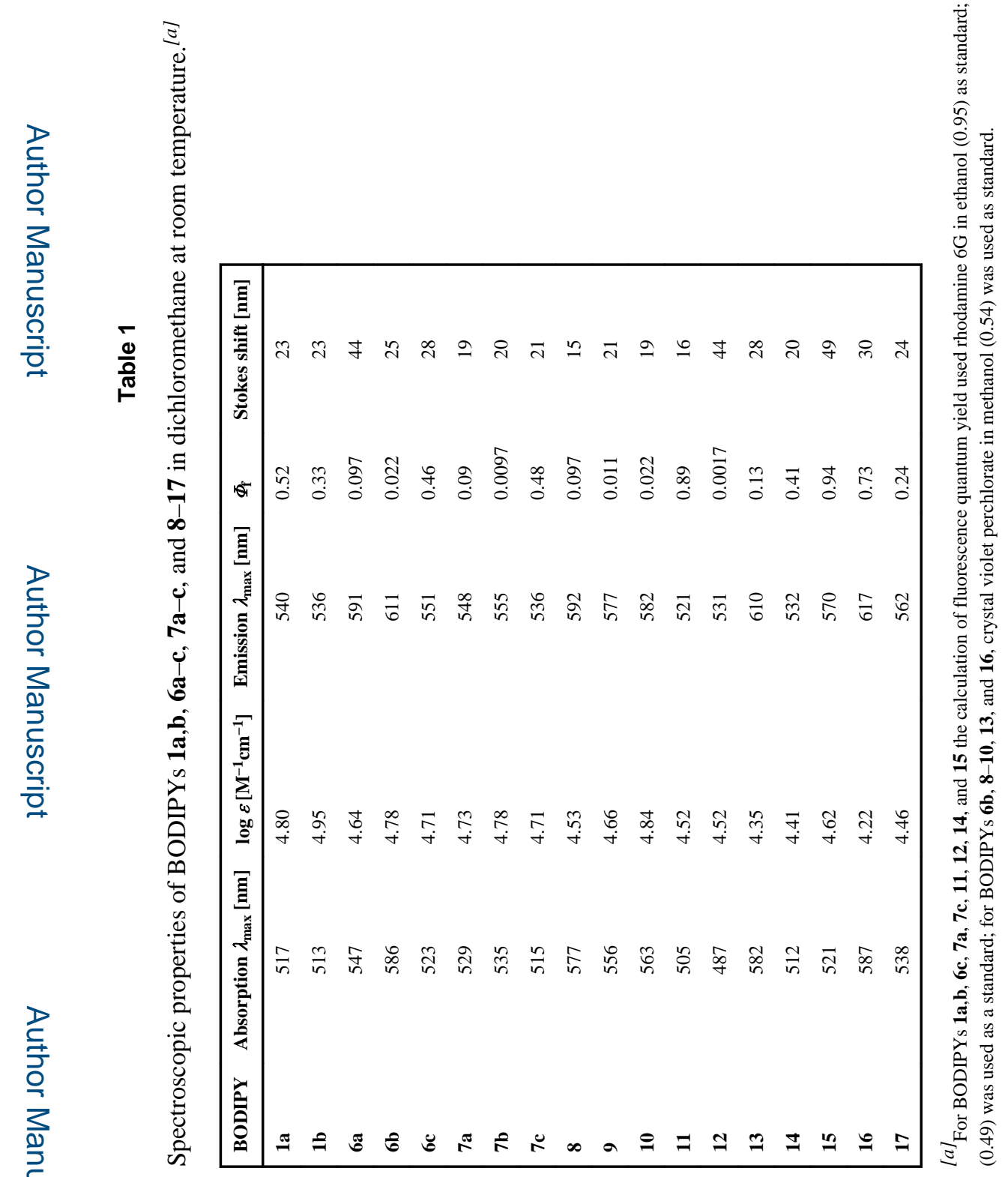

Chemistry. Author manuscript; available in PMC 2016 April 13. 